Conduct of Operations Applicability Matrix for CMELS Moderate Hazard Facilities at LLNL Site 300

H. R. Gregg

April 22, 2008 
This document was prepared as an account of work sponsored by an agency of the United States government. Neither the United States government nor Lawrence Livermore National Security, LLC, nor any of their employees makes any warranty, expressed or implied, or assumes any legal liability or responsibility for the accuracy, completeness, or usefulness of any information, apparatus, product, or process disclosed, or represents that its use would not infringe privately owned rights. Reference herein to any specific commercial product, process, or service by trade name, trademark, manufacturer, or otherwise does not necessarily constitute or imply its endorsement, recommendation, or favoring by the United States government or Lawrence Livermore National Security, LLC. The views and opinions of authors expressed herein do not necessarily state or reflect those of the United States government or Lawrence Livermore National Security, LLC, and shall not be used for advertising or product endorsement purposes.

This work performed under the auspices of the U.S. Department of Energy by Lawrence Livermore National Laboratory under Contract DE-AC52-07NA27344. 


\title{
Conduct of Operations Applicability Matrix for CMELS Moderate Hazard Facilities at LLNL Site $\mathbf{3 0 0}$
}

\author{
May 1, 2008
}

This Matrix applies to the following facilities:

CMELS Site 300 Facilities (Buildings 805, 806A-D, 807, 809A-C, 810A-C, 813, 817A-H, 821, 823A-B, 825, 826, 827A-E, 828A-C, 845A-B, 855A-C;

OS858; Magazines 2, 3, 4, 5, 10, 15, 33, 36, 51, 58, 816)

DISCLAIMER

This document was prepared as an account of work sponsored by an agency of the United States government. Neither the United States government nor Lawrence Livermore National Security, LLC, nor any of their employees makes any warranty, expressed or implied, or assumes any legal liability or responsibility for the accuracy, completeness, or usefulness of any information, apparatus, product, or process disclosed, or represents that its use would not infringe privately owned rights. Reference herein to any specific commercial product, process, or service by trade name, trademark, manufacturer, or otherwise does not necessarily constitute or imply its endorsement, recommendation, or favoring by the United States government or Lawrence Livermore National Security, LLC. The views and opinions of authors expressed herein do not necessarily state or reflect those of the United States government or Lawrence Livermore National Security, LLC, and shall not be used for advertising or product endorsement purposes.

This work performed under the auspices of the U.S. Department of Energy by Lawrence Livermore National Laboratory under Contract DE-AC52-07NA27344. 


\title{
Conduct of Operations Applicability Matrix CMELS Site 300
}

\begin{abstract}
May 1, 2008
This Matrix applies to the following facilities:

CMELS Site 300 Facilities (Buildings 805, 806A-D, 807, 809A-C, 810A-C, 813, 817A-H, 821, 823A-B, 825, 826, 827A-E, 828A-C, 845A-B, 855A-C;

OS858; Magazines 2, 3, 4, 5, 10, 15, 33, 36, 51, 816)
\end{abstract}

Matrix table based on the LLNL Environment Safety \& Health Manual Document 3.5, Conduct of Operations for LLNL Facilities

Prepared by Hugh Gregg, Site 300 Facility Manager, CMELS

Approved by Lori Souza, Deputy AD, Operations, CMELS

NNSA/LSO Approval

This document has been reviewed and verified not to contain classified information.

$\mathrm{ADC}$ 


\section{Conduct of Operations Applicability Matrix}

The following table documents applicability of the Conduct of Operations elements per ES\&H Manual Document 3.5, Conduct of Operations for LLNL Facilities, to operations in LLNL facilities. Applicable implementing documents, processes, and programs are listed.

\begin{tabular}{|c|c|c|c|c|}
\hline $\begin{array}{l}\text { ES\&H MANUAL } \\
\text { DOCUMENT } 3.5 \\
\text { SECTION } \\
\end{array}$ & $\begin{array}{l}\text { REQUISITES FOR SECTION } \\
\text { ELEMENTS }\end{array}$ & $\begin{array}{l}\text { APPLICABLE } \\
\text { YES/NO }\end{array}$ & $\begin{array}{c}\text { RESPONSIBILITY } \\
\text { FOR } \\
\text { COMPLIANCE } \\
\text { FMC/PMC }^{1} \\
\end{array}$ & $\begin{array}{l}\text { COMMENTS AND/OR REFERENCE FOR VERIFICATION OF } \\
\text { COMPLIANCE }\end{array}$ \\
\hline \multicolumn{5}{|l|}{$\begin{array}{l}\text { OPERATIONS } \\
\text { ORGANIZATION } \\
\text { ADMINISTRATION } \\
\text { SECTION } 1.0 \\
\end{array}$} \\
\hline $\begin{array}{l}\text { 1.2.1 Operations } \\
\text { Policies }\end{array}$ & $\begin{array}{l}\text { a) Operating policies and } \\
\text { procedures should be defined } \\
\text { (e.g., FSPs, IWS, IWS/SPs, } \\
\text { Work Procedures, Standard } \\
\text { Operating Procedures [SOPs]) } \\
\text { including responsibilities for } \\
\text { implementation. }\end{array}$ & Yes & FMC/PMC & $\begin{array}{l}\text { LLNL ES\&H Manual Documents } 2.1 \& 2.2 \\
\text { CMLS-330 ISMS Implementation Plan } \\
\text { S300.8 FSP for CMELS Site } 300 \text { Facility } \\
\text { FSP } 858 \text { FSP for Forensic Receival Facility }\end{array}$ \\
\hline 1.2.2. Resources & $\begin{array}{l}\text { a) A long-range staffing plan that } \\
\text { anticipates personnel losses } \\
\text { should be developed and } \\
\text { implemented for key positions } \\
\text { that require special training/ } \\
\text { qualification, certificates } \\
\text { and/or licenses. }\end{array}$ & No & NA & $\begin{array}{l}\text { Facilities don't contain operations or equipment that could result } \\
\text { in significant impact to ES\&H or programs. } \\
\text { Many of the operations do require training and qualifications (HE } \\
\text { handler, Crane certification, etc), however there are no Key } \\
\text { Positions identified that require a long-range staffing plan. }\end{array}$ \\
\hline & $\begin{array}{l}\text { b) Staffing levels should comply } \\
\text { with the level of ES\&H support } \\
\text { specified in resource planning } \\
\text { documents. }\end{array}$ & Yes & FMC/PMC & $\begin{array}{l}\text { CMLS-330 and ES\&H Manual Document } 2.1 \text { defines the role of } \\
\text { the Authorizing Organization to allocate sufficient resources to } \\
\text { ensure safe, efficient, and compliant operations. } \\
\text { CMLS-330 defines the roles of the CMELS DAD/Ops to oversee } \\
\text { and manage operations. The AD Resource Manager ensures } \\
\text { ES\&H needs are incorporated into budgets and resource } \\
\text { planning. }\end{array}$ \\
\hline
\end{tabular}

\footnotetext{
${ }^{1}$ Facility Management Chain/Program Management Chain
} 


\section{Conduct of Operations Applicability Matrix}

\begin{tabular}{|c|c|c|c|c|}
\hline $\begin{array}{l}\text { ES\&H MANUAL } \\
\text { DOCUMENT } 3.5 \\
\text { SECTION }\end{array}$ & $\begin{array}{l}\text { REQUISITES FOR SECTION } \\
\text { ELEMENTS }\end{array}$ & $\begin{array}{l}\text { APPLICABLE } \\
\text { YES/NO }\end{array}$ & $\begin{array}{l}\text { RESPONSIBILITY } \\
\text { FOR } \\
\text { COMPLIANCE } \\
\text { FMC/PMC }^{1} \\
\end{array}$ & $\begin{array}{l}\text { COMMENTS AND/OR REFERENCE FOR VERIFICATION OF } \\
\text { COMPLIANCE }\end{array}$ \\
\hline & $\begin{array}{l}\text { Define organizational } \\
\text { responsibilities for both } \\
\text { programmatic and support } \\
\text { organization personnel. }\end{array}$ & Yes & FMC/PMC & $\begin{array}{l}\text { CMLS-330 (Integrated Safety Management System [ISMSI) and } \\
\text { ES\&H Manual Document } 2.1 \text { (General Worker Responsibilities } \\
\text { and Integrated Safety Management) describes organizational } \\
\text { responsibilities for programmatic and support organizations. } \\
\text { This and most CMELS documents cited in this worksheet can be } \\
\text { found at the following URL: } \\
\text { http://sodium.IInl.gov/cmels/?url=library-policies_and_procedures } \\
\text { CMELS Organization Charts: } \\
\text { http://sodium.IInl.gov/cmels/?url=library-organizations } \\
\text { CMELS Site } 300 \text { Facilities and Contacts } \\
\text { http://cmsonly.IInl.gov/Facilities/site300faclist.html }\end{array}$ \\
\hline & $\begin{array}{l}\text { d) Identify the individual } \\
\text { responsible for implementing } \\
\text { the ES\&H controls in the FSP } \\
\text { or IWS/SP. }\end{array}$ & Yes & FMC & $\begin{array}{l}\text { CMLS-330 and ES\&H Manual Document } 2.1 \text { defines roles, } \\
\text { responsibilities, and authorities. } \\
\text { Responsibilities by role are also defined in CMELS Facility } \\
\text { Safety Plans (FSPs). For IWS/SPs the responsible individuals } \\
\text { are specifically named. }\end{array}$ \\
\hline \multirow[t]{2}{*}{$\begin{array}{l}\text { 1.2.3. Monitoring of } \\
\text { Operating } \\
\text { Performance }\end{array}$} & $\begin{array}{l}\text { a) Operating and safety goals } \\
\text { should be established. }\end{array}$ & Yes & FMC/PMC & $\begin{array}{l}\text { CMELS- } 330 \text { establishes commitments and metrics for meeting } \\
\text { LLNL safety goals, performance measures, and the success of } \\
\text { the ISMS. CMLS- } 330 \text { assigns responsibility to the Authorizing } \\
\text { Organization to define technical objectives of the work activity. } \\
\text { Programmatic goals are defined by each program (in each Work } \\
\text { request) and also in a broad sense in "LLNL Technical Strategic } \\
\text { Plan for High Explosives Technology," (UCRL-ID-128722, Dec. } \\
\text { 1997). }\end{array}$ \\
\hline & $\begin{array}{l}\text { b) Work supervisors or their } \\
\text { designees should regularly } \\
\text { observe important operational } \\
\text { activities to identify and correct } \\
\text { safety and operating } \\
\text { deficiencies. }\end{array}$ & Yes & FMC/PMC & $\begin{array}{l}\text { CMLS-305 (ES\&H Self-Assessment Plan) specifies schedules } \\
\text { and requirements for self-assessments. CMELS senior } \\
\text { management, Division management, and Work Supervisors } \\
\text { routinely observe operations in walk-arounds. } \\
\text { ES\&H Manual, Document 2.1, General Worker Responsibilities } \\
\text { and Integrated Safety Management }\end{array}$ \\
\hline
\end{tabular}




\section{Conduct of Operations Applicability Matrix}

\begin{tabular}{|c|c|c|c|c|}
\hline $\begin{array}{l}\text { ES\&H MANUAL } \\
\text { DOCUMENT } 3.5 \\
\text { SECTION }\end{array}$ & $\begin{array}{l}\text { REQUISITES FOR SECTION } \\
\text { ELEMENTS }\end{array}$ & $\begin{array}{l}\text { APPLICABLE } \\
\text { YES/NO }\end{array}$ & $\begin{array}{l}\text { RESPONSIBILITY } \\
\text { FOR } \\
\text { COMPLIANCE } \\
\text { FMC/PMC }^{1}\end{array}$ & $\begin{array}{l}\text { COMMENTS AND/OR REFERENCE FOR VERIFICATION OF } \\
\text { COMPLIANCE }\end{array}$ \\
\hline & $\begin{array}{l}\text { C) Document and evaluate } \\
\text { operating problems and } \\
\text { develop corrective actions to } \\
\text { improve performance. }\end{array}$ & Yes & FMC/PMC & $\begin{array}{l}\text { CMS-331 (Accident/Injury Prevention Program) defines } \\
\text { provisions for reviewing/analyzing safety data within the } \\
\text { Directorate. CMLS- } 305 \text { defines provisions for rolling up data to } \\
\text { the Institutional level for trending. } \\
\text { The CMELS Assurance Office also conducts an annual } \\
\text { assessment, which reports on trends within the directorate. }\end{array}$ \\
\hline \multirow[t]{2}{*}{$\begin{array}{l}1.2 .4 \text {. } \\
\text { Accountability }\end{array}$} & $\begin{array}{l}\text { a) Written performance } \\
\text { appraisals should provide } \\
\text { feedback to workers about } \\
\text { their safety and job } \\
\text { performance. }\end{array}$ & Yes & FMC/PMC & $\begin{array}{l}\text { CMLS-330 establishes requirements to ensure safety } \\
\text { accountability is part of the performance appraisal process. } \\
\text { CMLS-104 (Performance Appraisal, Ranking, and Salary Policy) } \\
\text { requires that the Performance Appraisal include information on } \\
\text { ES\&H responsibilities and expectations, and that employees be } \\
\text { appraised on the performance of those responsibilities. }\end{array}$ \\
\hline & $\begin{array}{l}\text { b) Formal performance } \\
\text { appraisals should be provided } \\
\text { at least annually and should } \\
\text { document operational } \\
\text { performance. }\end{array}$ & Yes & FMC/PMC & $\begin{array}{l}\text { CMLS-330 establishes requirements to ensure safety } \\
\text { accountability is part of the performance appraisal process. } \\
\text { CMLS-104 (Performance Appraisal, Ranking, and Salary Policy) } \\
\text { requires that the Performance Appraisal include information on } \\
\text { ES\&H responsibilities and expectations, and that employees be } \\
\text { appraised on the performance of those responsibilities. }\end{array}$ \\
\hline $\begin{array}{l}\text { 1.2.5. Management } \\
\text { Training }\end{array}$ & $\begin{array}{l}\text { a) Managers (NF/HHF/MHF) and } \\
\text { work supervisors (ALL) should } \\
\text { receive training in supervisory } \\
\text { skills, ES\&H issues specific to } \\
\text { the facility, and facility } \\
\text { operations in their area of } \\
\text { responsibility. }\end{array}$ & Yes & FMC/PMC & $\begin{array}{l}\text { CMLS-330 \& ES\&H Manual Document } 2.1 \text { establish Authorizing } \\
\text { Organization/Individual responsibilities to include designating an } \\
\text { appropriate RI and to provide support to that RI and to ensure } \\
\text { that individuals conducting the work possess the necessary } \\
\text { skills, knowledge, and abilities (SKA). } \\
\text { CMLS-330 assigns training responsibilities to the CMELS } \\
\text { DAD/Ops to manage the CMELS Training Program and assigns } \\
\text { responsibilities to Payroll Supervisors to develop personnel } \\
\text { skills to ensure necessary SKAs. The Payroll Supervisors also } \\
\text { ensure accuracy of the LTRAIN Questionnaire to develop } \\
\text { LTRAIN profiles to identify Institutional and Organizational } \\
\text { Training Requirements for managers and supervisors, and use } \\
\text { LTRAIN to track completion of those courses. }\end{array}$ \\
\hline
\end{tabular}




\section{Conduct of Operations Applicability Matrix}

\begin{tabular}{|c|c|c|c|c|}
\hline $\begin{array}{l}\text { ES\&H MANUAL } \\
\text { DOCUMENT } 3.5 \\
\quad \text { SECTION }\end{array}$ & $\begin{array}{l}\text { REQUISITES FOR SECTION } \\
\text { ELEMENTS }\end{array}$ & $\begin{array}{l}\text { APPLICABLE } \\
\text { YES/NO }\end{array}$ & $\begin{array}{l}\text { RESPONSIBILITY } \\
\text { FOR } \\
\text { COMPLIANCE } \\
\text { FMC/PMC }^{1}\end{array}$ & $\begin{array}{l}\text { COMMENTS AND/OR REFERENCE FOR VERIFICATION OF } \\
\text { COMPLIANCE }\end{array}$ \\
\hline $\begin{array}{l}\text { 1.2.6. Planning for } \\
\text { Safety }\end{array}$ & $\begin{array}{l}\text { a) Safety preplanning and review } \\
\text { process for routine work and } \\
\text { new processes or experiments } \\
\text { should be documented. }\end{array}$ & Yes & FMC/PMC & $\begin{array}{l}\text { CMLS-330 and ES\&H Manual Document } 2.1 \text { establishes the } \\
\text { Integration Work Sheet (IWS) process to review new work } \\
\text { activities not commonly performed by the public and to set } \\
\text { requirements to ensure operations are within the safety basis } \\
\text { envelope of each facility. } \\
\text { ES\&H Manual, Document 2.1, General Worker Responsibilities } \\
\text { and Integrated Safety Management }\end{array}$ \\
\hline $\begin{array}{l}\text { SHIFT ROUTINES } \\
\text { AND OPERATING } \\
\text { PRACTICES } \\
\text { SECTION } 2.0 \\
\end{array}$ & & & & \\
\hline $\begin{array}{l}\text { 2.2.1. Status } \\
\text { Practices }\end{array}$ & $\begin{array}{l}\text { a) Responsible } \\
\text { operators/workers should be } \\
\text { promptly notified of changes in } \\
\text { equipment or system status. }\end{array}$ & Yes & $\mathrm{FMC/PMC}$ & $\begin{array}{l}\text { CMELS S300 facilities do not utilize multiple shifts. Equipment } \\
\text { or systems for which prompt notification of status change is } \\
\text { required are identified in FSPs and IWSs. The methods of } \\
\text { notification are defined in these documents. }\end{array}$ \\
\hline & $\begin{array}{l}\text { b) Operators/workers should be } \\
\text { instructed to promptly notify } \\
\text { the facility and/or program } \\
\text { management chain (as } \\
\text { appropriate) of abnormalities; } \\
\text { abnormal, unusual or } \\
\text { emergency events; changes in } \\
\text { operational status; significant } \\
\text { changes in schedules; and } \\
\text { difficulties encountered in } \\
\text { performing tasks. }\end{array}$ & Yes & FMC/PMC & $\begin{array}{l}\text { CMLS-322 (Occurrence Reporting Plan) defines the occurrence } \\
\text { reporting processes. CMLS-330 and the FSPs also refer to the } \\
\text { processes defined in CMLS-322 (Occurrence Reporting Plan). } \\
\text { CMLS-330 discusses CMELS emergency response plans and } \\
\text { processes. FSPs also contain information on how to respond to } \\
\text { emergencies. } \\
\text { The CMS Site } 300 \text { Facility Emergency Self-Help Plan and } \\
\text { attached CMS Site } 300 \text { Employee Emergency Response Self- } \\
\text { Help Guide) (hard copies of this document are available in all } \\
\text { CMELS Site } 300 \text { facilities) also provides guidance to employees } \\
\text { on reporting unexpected events and unknowns. }\end{array}$ \\
\hline $\begin{array}{l}\text { 2.2.2. Safety } \\
\text { Practices }\end{array}$ & a) Develop safety plans. & Yes & FMC/PMC & $\begin{array}{l}\text { CMLS-330 and ES\&H Manual Document } 3.3 \text { (Facility Safety } \\
\text { Plans and Integration Work Sheets with Safety Plans) implement } \\
\text { the requirements to prepare FSPs and IWS/SPs. } \\
\text { The FSPs for CMELS facilities also provide guidance for when } \\
\text { IWS/SPs are required. } \\
\text { ES\&H Manual, Document 2.2, Managing ES\&H for LLNL Work }\end{array}$ \\
\hline
\end{tabular}




\section{Conduct of Operations Applicability Matrix}

\begin{tabular}{|c|c|c|c|c|}
\hline $\begin{array}{l}\text { ES\&H MANUAL } \\
\text { DOCUMENT } 3.5 \\
\text { SECTION }\end{array}$ & $\begin{array}{c}\text { REQUISITES FOR SECTION } \\
\text { ELEMENTS }\end{array}$ & $\begin{array}{l}\text { APPLICABLE } \\
\text { YES/NO }\end{array}$ & $\begin{array}{l}\text { RESPONSIBILITY } \\
\text { FOR } \\
\text { COMPLIANCE } \\
\text { FMC/PMC }^{1}\end{array}$ & $\begin{array}{l}\text { COMMENTS AND/OR REFERENCE FOR VERIFICATION OF } \\
\text { COMPLIANCE }\end{array}$ \\
\hline & $\begin{array}{l}\text { b) Workers are trained to } \\
\text { properly operate equipment } \\
\text { and understand the safety } \\
\text { plans. }\end{array}$ & Yes & FMC/PMC & $\begin{array}{l}\text { CMLS-330 and ES\&H Manual Document } 2.1 \text { directs the RI to } \\
\text { ensure worker qualifications including an understanding of the } \\
\text { FSP and IWS/SP. } \\
\text { Facility management provides FSP briefings to Site } 300 \text { facility } \\
\text { residents. } \\
\text { OJT is provided for many of the pieces of equipment used } \\
\text { during CMELS operations at Site } 300 \text {. } \\
\text { ES\&H Manual, Document } 40.2 \\
\text { ES\&H Manual, Document } 22.1 \text {, Emergency Preparedness and } \\
\text { Response }\end{array}$ \\
\hline & $\begin{array}{l}\text { c) Adhere to requirements in the } \\
\text { Industrial safety program. }\end{array}$ & Yes & FMC & $\begin{array}{l}\text { The Industrial Safety (IS) Program is documented in the IS } \\
\text { Discipline Action Plans (DAP) maintained by ES\&H Teams } 4 \\
\text { (Site } 300) \text {, which captures the requirements of the ES\&H } \\
\text { Manual. } \\
\text { ES\&H Manual, Documents } 11.1,11.2,15.2,16.1,17.1,18.1 \text {, } \\
\text { 18.5, 22.4. and } 42.1\end{array}$ \\
\hline & $\begin{array}{l}\text { d) Adhere to requirements in the } \\
\text { Health physics program. }\end{array}$ & Yes & FMC & $\begin{array}{l}\text { The Health Physics (HP) Program is documented in the HP } \\
\text { DAP maintained by ES\&H Teams } 4 \text { (Site } 300) \text {, which captures } \\
\text { the requirements of the ES\&H Manual. } \\
\text { ES\&H Manual, Document 20.1, Occupational Radiation } \\
\text { Protection }\end{array}$ \\
\hline & $\begin{array}{l}\text { e) Adhere to requirements in the } \\
\text { Industrial hygiene program. }\end{array}$ & Yes & FMC & $\begin{array}{l}\text { The Industrial Hygiene }(\mathrm{IH}) \text { Program is documented in the IH } \\
\text { DAP maintained by ES\&H Teams } 4 \text { (Site } 300) \text {, which captures } \\
\text { the requirements of the ES\&H Manual. } \\
\text { ES\&H Manual, Documents } 11.1,11.2,12.2,13.1 \text {, and } 14.1\end{array}$ \\
\hline
\end{tabular}




\section{Conduct of Operations Applicability Matrix}

\begin{tabular}{|c|c|c|c|c|c|}
\hline $\begin{array}{l}\text { ES\&H MANUAL } \\
\text { DOCUMENT } 3.5 \\
\text { SECTION } \\
\end{array}$ & & $\begin{array}{l}\text { REQUISITES FOR SECTION } \\
\text { ELEMENTS }\end{array}$ & $\begin{array}{l}\text { APPLICABLE } \\
\text { YES/NO }\end{array}$ & $\begin{array}{l}\text { RESPONSIBILITY } \\
\text { FOR } \\
\text { COMPLIANCE } \\
\text { FMC/PMC }^{1}\end{array}$ & $\begin{array}{l}\text { COMMENTS AND/OR REFERENCE FOR VERIFICATION OF } \\
\text { COMPLIANCE }\end{array}$ \\
\hline & & $\begin{array}{l}\text { Adhere to requirements in the } \\
\text { Criticality safety program. }\end{array}$ & Yes & FMC & $\begin{array}{l}\text { The Criticality Safety Program is documented in the Criticality } \\
\text { DAP maintained by ES\&H Team } 4 \text { (Site } 300 \text { ), which captures } \\
\text { the requirements of the ES\&H Manual. In addition, the Criticality } \\
\text { Safety Section of the Hazards Control Department reviews } \\
\text { activities involving the potential for nuclear criticality at the } \\
\text { request the Health Physicist or Facility Management. } \\
\text { ES\&H Manual, Document } 20.6 \text {, Criticality Safety }\end{array}$ \\
\hline & & $\begin{array}{l}\text { Adhere to requirements in the } \\
\text { Fire safety program. }\end{array}$ & Yes & FMC & $\begin{array}{l}\text { The Fire Safety (FS) Program is documented in the Fire } \\
\text { Protection DAP maintained by ES\&H Teams } 4 \text { (Site } 300) \text {, which } \\
\text { captures the requirements of the ES\&H Manual. } \\
\text { ES\&H Manual, Document 22.5, Fire }\end{array}$ \\
\hline & & $\begin{array}{l}\text { Adhere to requirements in the } \\
\text { Environmental protection } \\
\text { program. }\end{array}$ & Yes & FMC & $\begin{array}{l}\text { The Environmental Protection Program is documented in the } \\
\text { Environmental Protection DAP maintained by ES\&H Teams } 4 \\
\text { (Site } 300 \text { ), which captures the requirements of the ES\&H } \\
\text { Manual. The electronic IWS system documents NEPA and other } \\
\text { environmental reviews. More information regarding the } \\
\text { environmental protection program can be found in Volume II of } \\
\text { the ES\&H Manual. } \\
\text { ES\&H Manual, Document } 30.1\end{array}$ \\
\hline & & $\begin{array}{l}\text { Adhere to requirements in the } \\
\text { ALARA program. }\end{array}$ & Yes & FMC/PMC & $\begin{array}{l}\text { CMELS Site } 300 \text { facilities do not require a formal ALARA } \\
\text { program in accordance with the LLNL ES\&H Manual Document } \\
20.4 \text { (LLNL Occupational Radiation Protection ALARA Program) } \\
\text { since individual occupational radiation doses in the facility are } \\
\text { not likely to exceed } 100 \text { mrem/year. However, CMELS FSPs } \\
\text { stress ALARA goals, and CMLS- } 330 \text { requires RIs to integrate } \\
\text { ALARA philosophy into operations. } \\
\text { ES\&H Manual, Document } 20.4\end{array}$ \\
\hline $\begin{array}{l}\text { 2.2.3. Operator } \\
\text { Inspection Tours }\end{array}$ & a) & $\begin{array}{l}\text { Procedures for Operator/FC } \\
\text { tours should follow the } \\
\text { guidance in Section 2.2.3. }\end{array}$ & Yes & FMC & $\begin{array}{l}\text { Daily shift tours are not utilized in these facilities due to the low } \\
\text { anticipated consequences of delayed discovery of abnormal } \\
\text { conditions. }\end{array}$ \\
\hline
\end{tabular}




\section{Conduct of Operations Applicability Matrix}

\begin{tabular}{|c|c|c|c|c|}
\hline $\begin{array}{l}\text { ES\&H MANUAL } \\
\text { DOCUMENT } 3.5 \\
\text { SECTION }\end{array}$ & $\begin{array}{l}\text { REQUISITES FOR SECTION } \\
\text { ELEMENTS }\end{array}$ & $\begin{array}{l}\text { APPLICABLE } \\
\text { YES/NO }\end{array}$ & $\begin{array}{l}\text { RESPONSIBILITY } \\
\text { FOR } \\
\text { COMPLIANCE } \\
\text { FMC/PMC }^{1} \\
\end{array}$ & $\begin{array}{l}\text { COMMENTS AND/OR REFERENCE FOR VERIFICATION OF } \\
\text { COMPLIANCE }\end{array}$ \\
\hline $\begin{array}{l}\text { 2.2.4. Round/Tour } \\
\text { Inspection Sheets }\end{array}$ & $\begin{array}{l}\text { a) Procedures for Round/Tour } \\
\text { Inspection Sheets should } \\
\text { follow the guidance in Section } \\
\text { 2.2.4. }\end{array}$ & Yes & FMC & $\begin{array}{l}\text { Daily shift tours are not utilized in these facilities due to the low } \\
\text { anticipated consequences of delayed discovery of abnormal } \\
\text { conditions. }\end{array}$ \\
\hline \multirow[t]{2}{*}{$\begin{array}{l}\text { 2.2.5. Personnel } \\
\text { Protection }\end{array}$} & $\begin{array}{l}\text { a) In addition to the discussion in } \\
\text { Section } 2.2 .2 \text { (Safety } \\
\text { Practices), applicable } \\
\text { personnel training/qualification } \\
\text { should include the guidance in } \\
\text { Section 2.2.5. }\end{array}$ & Yes & FMC/PMC & $\begin{array}{l}\text { Operations personnel are trained to understand and comply with } \\
\text { all area postings for exposure warnings and PPE requirements. }\end{array}$ \\
\hline & $\begin{array}{l}\text { b) Supervisors should review } \\
\text { exposure trends. }\end{array}$ & Yes & $\mathrm{FMC/PMC}$ & $\begin{array}{l}\text { Document 20.4, "LLNL Occupational Radiation Protection } \\
\text { ALARA Program," requires ES\&H Team Health Physicists } \\
\text { submittal of notable trends or ALARA issues to facility and } \\
\text { program management when facilities have established ALARA } \\
\text { goals. }\end{array}$ \\
\hline $\begin{array}{l}\text { 2.2.6. Response to } \\
\text { Indications }\end{array}$ & $\begin{array}{l}\text { a) Response to Indications } \\
\text { should follow the guidance in } \\
\text { Section 2.2.6. }\end{array}$ & Yes & $\mathrm{FMC/PMC}$ & $\begin{array}{l}\text { Response to abnormal indications are detailed in the IWSs } \\
\text { and/or FSPs. }\end{array}$ \\
\hline $\begin{array}{l}\text { 2.2.7. Resetting } \\
\text { Protective Devices }\end{array}$ & $\begin{array}{l}\text { a) Establish controls for resetting } \\
\text { protective devices whose } \\
\text { improper positioning/ } \\
\text { operation could result in an } \\
\text { impact to health, safety, the } \\
\text { environment, }\end{array}$ & Yes & FMC/PMC & $\begin{array}{l}\text { Protective devices (other than circuit breakers, GFCls, and } \\
\text { fuses) and the appropriate response to a trip condition are } \\
\text { identified in applicable safety plans. Section } 8.2 \text { of ES\&H } \\
\text { Manual Document } 16.1 \text { "Electrical Safety Program" } \\
\text { recommends supplemental training for workers who reset } \\
\text { overcurrent protective devices. }\end{array}$ \\
\hline $\begin{array}{l}\text { 2.2.8. Load } \\
\text { Changes }\end{array}$ & $\begin{array}{l}\text { a) Establish that load changes } \\
\text { have been addressed. }\end{array}$ & No & $\mathrm{N} / \mathrm{A}$ & $\begin{array}{l}\text { This attribute is not applicable (i.e. these facilities do not perform } \\
\text { load changes). }\end{array}$ \\
\hline
\end{tabular}




\section{Conduct of Operations Applicability Matrix}

\begin{tabular}{|c|c|c|c|c|}
\hline $\begin{array}{l}\text { ES\&H MANUAL } \\
\text { DOCUMENT } 3.5 \\
\quad \text { SECTION }\end{array}$ & $\begin{array}{l}\text { REQUISITES FOR SECTION } \\
\text { ELEMENTS }\end{array}$ & $\begin{array}{l}\text { APPLICABLE } \\
\text { YES/NO }\end{array}$ & $\begin{array}{l}\text { RESPONSIBILITY } \\
\text { FOR } \\
\text { COMPLIANCE } \\
\text { FMC/PMC }^{1}\end{array}$ & $\begin{array}{l}\text { COMMENTS AND/OR REFERENCE FOR VERIFICATION OF } \\
\text { COMPLIANCE }\end{array}$ \\
\hline $\begin{array}{l}\text { 2.2.9. Authority to } \\
\text { Operate Equipment }\end{array}$ & $\begin{array}{l}\text { a) Identify personnel authorized } \\
\text { to operate facility equipment } \\
\text { whose improper operation } \\
\text { could result in an impact to } \\
\text { health, safety, the } \\
\text { environment, }\end{array}$ & Yes & FMC/PMC & $\begin{array}{l}\text { The lead technicians for each area are the operations } \\
\text { supervisor and are aware of all activities affecting equipment. } \\
\text { This is documented in the FSP }\end{array}$ \\
\hline $\begin{array}{l}\text { 2.2.10. Shift } \\
\text { Operating Bases }\end{array}$ & $\begin{array}{l}\text { a) Establish shift operating bases } \\
\text { for each shift position. }\end{array}$ & Yes & FMC & $\begin{array}{l}\text { Facilities don't contain operations or equipment that warrant } \\
\text { designation of a shift operating base. }\end{array}$ \\
\hline $\begin{array}{l}\text { 2.2.11. Potentially } \\
\text { Distractive Written } \\
\text { Material and } \\
\text { Devices }\end{array}$ & $\begin{array}{l}\text { a) Identify controls for Potentially } \\
\text { Distractive Written Material } \\
\text { and Devices. }\end{array}$ & Yes & FMC & $\begin{array}{l}\text { Facilities don't contain operations or equipment that could result } \\
\text { in significant impact to ES\&H or programs that warrant these } \\
\text { controls. }\end{array}$ \\
\hline \multicolumn{5}{|l|}{$\begin{array}{l}\text { CONTROL AREA } \\
\text { ACTIVITIES FOR } \\
\text { DOE FACILITIES } \\
\text { SECTION } 3.0 \\
\end{array}$} \\
\hline \multirow[t]{2}{*}{$\begin{array}{l}\text { 3.2.1. Control Area } \\
\text { Access }\end{array}$} & $\begin{array}{l}\text { a) Control rooms associated with } \\
\text { systems, equipment or } \\
\text { processes where operator } \\
\text { error could result in significant } \\
\text { impact to health, safety, the } \\
\text { environment or to programs } \\
\text { are identified and physically } \\
\text { delineated }\end{array}$ & Yes & $\mathrm{FMC/PMC}$ & $\begin{array}{l}\text { At Site } 300 \text {, the entrances to all Control Rooms are clearly } \\
\text { labeled as such. In addition, FSP S300.8 identifies control room } \\
\text { activities and locations in sections } 1,3,8,9,11 \text {, and Appendix } \\
\text { A. }\end{array}$ \\
\hline & $\begin{array}{l}\text { b) Specify personnel who are } \\
\text { authorized for access to } \\
\text { control rooms }\end{array}$ & Yes & $\mathrm{FMC/PMC}$ & $\begin{array}{l}\text { Only activities related to the operation or specifically authorized } \\
\text { by management shall be authorized in the control room when the } \\
\text { equipment or system is being operated. } \\
\text { Section } 3.2 .2 .2 \text { of FSP S300.8 defines personnel and } \\
\text { operational access controls for Site } 300 \text {. CMLS- } 330 \text { and the } \\
\text { ES\&H Manual 2.1. }\end{array}$ \\
\hline
\end{tabular}




\section{Conduct of Operations Applicability Matrix}

\begin{tabular}{|c|c|c|c|c|c|}
\hline $\begin{array}{l}\text { ES\&H MANUAL } \\
\text { DOCUMENT } 3.5 \\
\text { SECTION }\end{array}$ & & $\begin{array}{l}\text { REQUISITES FOR SECTION } \\
\text { ELEMENTS }\end{array}$ & $\begin{array}{l}\text { APPLICABLE } \\
\text { YES/NO }\end{array}$ & $\begin{array}{l}\text { RESPONSIBILITY } \\
\text { FOR } \\
\text { COMPLIANCE } \\
\text { FMC/PMC }^{1}\end{array}$ & $\begin{array}{l}\text { COMMENTS AND/OR REFERENCE FOR VERIFICATION OF } \\
\text { COMPLIANCE }\end{array}$ \\
\hline $\begin{array}{l}\text { 3.2.2. Professional } \\
\text { behavior }\end{array}$ & & $\begin{array}{l}\text { Control room activities are } \\
\text { limited to those essential for } \\
\text { supporting operations. }\end{array}$ & Yes & $\mathrm{FMC/PMC}$ & $\begin{array}{l}\text { At Site } 300 \text { area Supervisors, Lead Technicians, and PL ensure } \\
\text { that only activities related to the operation or specifically } \\
\text { authorized by management are authorized in the control room } \\
\text { during activation. Potentially distracting activities are prohibited. } \\
\text { Controls for behavior are set in the IWS, CMLS-330, FSPs and } \\
\text { the ES\&H Manual 2.1. }\end{array}$ \\
\hline $\begin{array}{l}\text { 3.2.3. Monitoring } \\
\text { the Main Control } \\
\text { Panels }\end{array}$ & & $\begin{array}{l}\text { Responsible operators should } \\
\text { understand their responsibility } \\
\text { for monitoring control room } \\
\text { panels, including timely } \\
\text { response to alarm conditions. }\end{array}$ & Yes & $\mathrm{FMC/PMC}$ & $\begin{array}{l}\text { At Site } 300 \text { control room remote operations utilize automatic } \\
\text { interlock systems to provide immediate notification and to } \\
\text { suspend further operations in the event of any critical systems } \\
\text { malfunction. Additionally, abnormal operating parameters are } \\
\text { continuously monitored at the control room console. } \\
\text { More information is available in FSP } 300.8 \text {. }\end{array}$ \\
\hline $\begin{array}{l}\text { 3.2.4. Control } \\
\text { Operator Ancillary } \\
\text { Duties }\end{array}$ & & $\begin{array}{l}\text { Ancillary duties should not } \\
\text { interfere with the operators' } \\
\text { shift responsibilities. }\end{array}$ & Yes & $\mathrm{FMC/PMC}$ & $\begin{array}{l}\text { Controls for ancillary duties are set in the IWS, CMLS- } 330 \text {, } \\
\text { FSPs and the ES\&H Manual 2.1. }\end{array}$ \\
\hline $\begin{array}{l}\text { 3.2.5. Operation of } \\
\text { Control Area } \\
\text { Equipment }\end{array}$ & a) & $\begin{array}{l}\text { Only authorized personnel } \\
\text { shall operate control area } \\
\text { equipment. }\end{array}$ & Yes & $\mathrm{FMC/PMC}$ & $\begin{array}{l}\text { Sections 3.2.2.2.6 and 3.2.2.2.7 of FSP S300.8 identifies the } \\
\text { Operator-in-Charge (Process Area and Chemistry Area) as } \\
\text { controlling remote operations, including operation of the control } \\
\text { room and key for Site } 300 .\end{array}$ \\
\hline \multicolumn{6}{|l|}{$\begin{array}{l}\text { COMMUNICATIONS } \\
\text { SECTION } 4.0\end{array}$} \\
\hline $\begin{array}{l}\text { 4.2.1. Emergency } \\
\text { Communications } \\
\text { Systems }\end{array}$ & & $\begin{array}{l}\text { Ensure ready notification of } \\
\text { workers during routine and } \\
\text { emergency conditions. }\end{array}$ & Yes & FMC & $\begin{array}{l}\text { Building intercom, emergency paging system, postings on } \\
\text { equipment or facility entrances, or emergency bullhorns are } \\
\text { available. An emergency call list is maintained by the Facility } \\
\text { Manager. The Site } 300 \text { Lightning Detection and Warning } \\
\text { System provides direct radio-pager and indirect trunked radio } \\
\text { system notification to workers in the CMLS Site } 300 \text { Facilities, } \\
\text { (Section 3.2.2.3.12, CMELS Site } 300 \text { FSP S300.8). } \\
\text { Document 22.1, Emergency Preparedness and Response }\end{array}$ \\
\hline
\end{tabular}




\section{Conduct of Operations Applicability Matrix}

\begin{tabular}{|c|c|c|c|c|}
\hline $\begin{array}{l}\text { ES\&H MANUAL } \\
\text { DOCUMENT } 3.5 \\
\text { SECTION }\end{array}$ & $\begin{array}{l}\text { REQUISITES FOR SECTION } \\
\text { ELEMENTS }\end{array}$ & $\begin{array}{l}\text { APPLICABLE } \\
\text { YES/NO }\end{array}$ & $\begin{array}{l}\text { RESPONSIBILITY } \\
\text { FOR } \\
\text { COMPLIANCE } \\
\text { FMC/PMC } \\
\end{array}$ & $\begin{array}{l}\text { COMMENTS AND/OR REFERENCE FOR VERIFICATION OF } \\
\text { COMPLIANCE }\end{array}$ \\
\hline & $\begin{array}{l}\text { b) Emergency communications } \\
\text { are regularly tested for } \\
\text { functionality. }\end{array}$ & Yes & FMC/PMC & $\begin{array}{l}\text { Plant Engineering conducts routine PM and testing of alarm } \\
\text { systems. } \\
\text { LLNL Site emergency communications systems are tested daily } \\
\text { by the LLNL Alarms Division }\end{array}$ \\
\hline $\begin{array}{l}\text { 4.2.2. Public } \\
\text { Address System }\end{array}$ & $\begin{array}{l}\text { a) Public Address system is } \\
\text { administratively controlled. }\end{array}$ & Yes & FMC/PMC & $\begin{array}{l}\text { LLNL Alarms Division controls the Site emergency } \\
\text { communication system }\end{array}$ \\
\hline \multirow[t]{4}{*}{$\begin{array}{l}\text { 4.2.3. Contacting } \\
\text { Operators }\end{array}$} & $\begin{array}{l}\text { a) Provide functional } \\
\text { communication devices } \\
\text { (telephones, paging systems) } \\
\text { within the facility and } \\
\text { immediate area. }\end{array}$ & Yes & FMC & $\begin{array}{l}\text { Telephones throughout occupied facilities, emergency paging } \\
\text { system, radio pagers, two-way radios for facility operations staff } \\
\text { and electronic mail provide rapid communications. Additionally, } \\
\text { the indirect trunked radio system is used in remote locations at } \\
\text { Site } 300 \text {. }\end{array}$ \\
\hline & $\begin{array}{l}\text { b) Provide safety alarms. Visual } \\
\text { alarms should be used in } \\
\text { noisy areas where audible } \\
\text { alarms may go unnoticed. }\end{array}$ & Yes & FMC & $\begin{array}{l}\text { Malfunctions of the telephones, building paging system, pagers, } \\
\text { and electronic mail are infrequent. Telephone, alarms, and radio } \\
\text { page systems have either battery or emergency back-up power. } \\
\text { ES\&H Manual, Document } 12.1\end{array}$ \\
\hline & $\begin{array}{l}\text { c) Communication systems } \\
\text { should be available in remote } \\
\text { areas where work is } \\
\text { conducted, such as } \\
\text { basements, lofts, and } \\
\text { equipment rooms. }\end{array}$ & Yes & FMC & $\begin{array}{l}\text { Building intercom and radio page provide coverage in out-of the- } \\
\text { way portions of the facilities. Additionally, the indirect trunked } \\
\text { radio system is used in remote locations at Site } 300 \text {. }\end{array}$ \\
\hline & $\begin{array}{l}\text { d) As appropriate, provisions } \\
\text { should exist for locating key } \\
\text { workers during off-hours, and } \\
\text { during the workday while they } \\
\text { are outside the facility. }\end{array}$ & Yes & FMC/PMC & $\begin{array}{l}\text { Key operational personnel can be reached via radio pager, } \\
\text { trunked radio system and government-owned cellular telephone } \\
\text { systems. Lists of emergency contact numbers are maintained by } \\
\text { the CMELS payroll organizations. }\end{array}$ \\
\hline 4.2.4. Radios & $\begin{array}{l}\text { a) Areas where radios are } \\
\text { prohibited should be } \\
\text { delineated. }\end{array}$ & YES & FMC/PMC & Areas where radios are prohibited are posted. \\
\hline
\end{tabular}




\section{Conduct of Operations Applicability Matrix}

\begin{tabular}{|c|c|c|c|c|}
\hline $\begin{array}{l}\text { ES\&H MANUAL } \\
\text { DOCUMENT } 3.5 \\
\text { SECTION }\end{array}$ & $\begin{array}{l}\text { REQUISITES FOR SECTION } \\
\text { ELEMENTS }\end{array}$ & $\begin{array}{l}\text { APPLICABLE } \\
\text { YES/NO }\end{array}$ & $\begin{array}{l}\text { RESPONSIBILITY } \\
\text { FOR } \\
\text { COMPLIANCE } \\
\text { FMC/PMC }^{1}\end{array}$ & $\begin{array}{l}\text { COMMENTS AND/OR REFERENCE FOR VERIFICATION OF } \\
\text { COMPLIANCE }\end{array}$ \\
\hline $\begin{array}{l}\text { 4.2.5. Abbreviations } \\
\text { and Acronyms }\end{array}$ & $\begin{array}{l}\text { a) In emergency } \\
\text { communications, limit use of } \\
\text { abbreviations and acronyms to } \\
\text { those in approved LLNL } \\
\text { documents. }\end{array}$ & Yes & FMC/PMC & $\begin{array}{l}\text { Some abbreviations and acronyms are used. They are defined } \\
\text { in the FSP } 300.8 \text {. } \\
\text { LLNL Alarms Division controls the Site emergency } \\
\text { communication system and as a general rule do not use } \\
\text { acronyms in emergency communications }\end{array}$ \\
\hline $\begin{array}{l}\text { 4.2.6. Oral } \\
\text { instructions and } \\
\text { Informal } \\
\text { Communications }\end{array}$ & $\begin{array}{l}\text { a) Oral Instructions and } \\
\text { Informational Communications } \\
\text { should follow the guidance in } \\
\text { Section 4.2.6. }\end{array}$ & Yes & $\mathrm{FMC} / \mathrm{PMC}$ & $\begin{array}{l}\text { Oral instructions involving equipment operations should be clear } \\
\text { and concise and should be repeated by the receiver to the } \\
\text { extent necessary to ensure instructions are clearly understood. }\end{array}$ \\
\hline \multicolumn{5}{|l|}{$\begin{array}{l}\text { CONTROL OF ON- } \\
\text { SHIFT TRAINING } \\
\text { SECTION } 5.0\end{array}$} \\
\hline $\begin{array}{l}\text { 5.2.1. Adherence to } \\
\text { Training Programs }\end{array}$ & a) Identify tasks requiring OJT. & Yes & PMC & $\begin{array}{l}\text { OJT requirements are identified in Document } 40.1 \text { (LLNL } \\
\text { Training Program Manual) and CMLS- } 330 \text {. CMLS- } 330 \text { requires } \\
\text { the RI to ensure required training, including on-the-job training } \\
\text { (OJT), is completed and to ensure workers have necessary } \\
\text { qualifications. ES\&H Document } 17.7 \text { requires formal OJT } \\
\text { training for explosives handlers. }\end{array}$ \\
\hline $\begin{array}{l}\text { 5.2.2. On-shift } \\
\text { Instructor } \\
\text { Qualifications }\end{array}$ & $\begin{array}{l}\text { a) Document instructor and } \\
\text { evaluator qualifications. }\end{array}$ & Yes & PMC & $\begin{array}{l}\text { Qualifications for OJT training instructors are determined by } \\
\text { education, experience, background, subject area knowledge, } \\
\text { and the ability to instruct others. Al and RI specify individuals } \\
\text { authorized to conduct OJT for specific facilities, equipment, or } \\
\text { operations. Completions of formal degree programs are } \\
\text { documented in personnel records. Completions of classes } \\
\text { during LLNL employment are recorded in LTRAIN. } \\
\text { Document } 40.1\end{array}$ \\
\hline $\begin{array}{l}\text { 5.2.3. Qualified } \\
\text { Operator } \\
\text { Supervision and } \\
\text { Control of Trainees }\end{array}$ & $\begin{array}{l}\text { a) Establish protocol for } \\
\text { supervision and control of } \\
\text { trainees. }\end{array}$ & Yes & PMC & $\begin{array}{l}\text { FSPs, IWS/SPs, and/or IWSs define (as appropriate) conditions } \\
\text { under which trainees may be used to support potentially } \\
\text { hazardous work activities. The IWS lists names of qualified } \\
\text { personnel to do the work activity. }\end{array}$ \\
\hline
\end{tabular}




\section{Conduct of Operations Applicability Matrix}

\begin{tabular}{|c|c|c|c|c|}
\hline $\begin{array}{l}\text { ES\&H MANUAL } \\
\text { DOCUMENT } 3.5 \\
\text { SECTION }\end{array}$ & $\begin{array}{l}\text { REQUISITES FOR SECTION } \\
\text { ELEMENTS }\end{array}$ & $\begin{array}{l}\text { APPLICABLE } \\
\text { YES/NO }\end{array}$ & $\begin{array}{l}\text { RESPONSIBILITY } \\
\text { FOR } \\
\text { COMPLIANCE } \\
\text { FMC/PMC }^{1}\end{array}$ & $\begin{array}{l}\text { COMMENTS AND/OR REFERENCE FOR VERIFICATION OF } \\
\text { COMPLIANCE }\end{array}$ \\
\hline & $\begin{array}{l}\text { b) Ensure trainee awareness of } \\
\text { hazards and operating limits. }\end{array}$ & Yes & PMC & $\begin{array}{l}\text { CMLS- } 330 \text { requires the RI to ensure that trainees only work } \\
\text { according to existing procedures and IWSs, and that they are } \\
\text { aware of operating limits and hazards. CMLS- } 330 \text { requires the } \\
\text { RI to ensure visitors, guests, students, and vendors either have } \\
\text { the required training or work under the direct supervision of a } \\
\text { qualified worker. }\end{array}$ \\
\hline $\begin{array}{l}\text { 5.2.4. Operator } \\
\text { Qualification } \\
\text { Program Approval }\end{array}$ & $\begin{array}{l}\text { a) Ensure the appropriate area } \\
\text { supervisor has approved the } \\
\text { OJT. }\end{array}$ & Yes & PMC & $\begin{array}{l}\text { The RI documents and either provides or approves OJT for } \\
\text { personnel working under their direction. This process is reflected } \\
\text { in the IWS authorizing the work. } \\
\text { Formal OJT programs, such as Explosive Handler Qualifications } \\
\text { (e.g. Document 17.7), may substitute for the RI documentation } \\
\text { specified above. }\end{array}$ \\
\hline $\begin{array}{l}\text { 5.2.5. Training } \\
\text { Documentation }\end{array}$ & a) Document OJT. & Yes & PMC & $\begin{array}{l}\text { OJT training is documented in the Training Qualification Record } \\
\text { maintained by the payroll supervisor in accordance with } \\
\text { Document } 40.1 \text { (LLNL Training Program Manual). CMLS- } 330 \\
\text { defines record keeping requirements for training records. }\end{array}$ \\
\hline $\begin{array}{l}\text { 5.2.6. Suspension } \\
\text { of Training }\end{array}$ & $\begin{array}{l}\text { a) Ensure trainees understand } \\
\text { their role during abnormal } \\
\text { conditions. }\end{array}$ & Yes & $\mathrm{FMC} / \mathrm{PMC}$ & $\begin{array}{l}\text { CMLS-330 requires the RI to ensure that trainees only work with } \\
\text { experienced personnel according to existing procedures, and } \\
\text { that they are aware of operating limits and hazards. CMLS- } 330 \\
\text { requires the host and RI to ensure visitors, guests, students, } \\
\text { and vendors either have the required training or are escorted. }\end{array}$ \\
\hline $\begin{array}{l}\text { 5.2.7. Maximum } \\
\text { Number of Trainees }\end{array}$ & $\begin{array}{l}\text { a) Establish limits for the number } \\
\text { of OJT trainees. }\end{array}$ & No & NA & $\begin{array}{l}\text { CMELS does not limit the number of OJT trainees. OJT } \\
\text { requirements are identified in Document } 40.1 \text { (LLNL Training } \\
\text { Program Manual) and CMLS- } 330 \text { requires the RI to ensure } \\
\text { required training, including on-the-job training (OJT) for all } \\
\text { trainees, is completed and to ensure workers have necessary } \\
\text { qualifications. ES\&H Document } 17.7 \text { requires formal OJT } \\
\text { training for explosives handlers. }\end{array}$ \\
\hline
\end{tabular}




\section{Conduct of Operations Applicability Matrix}

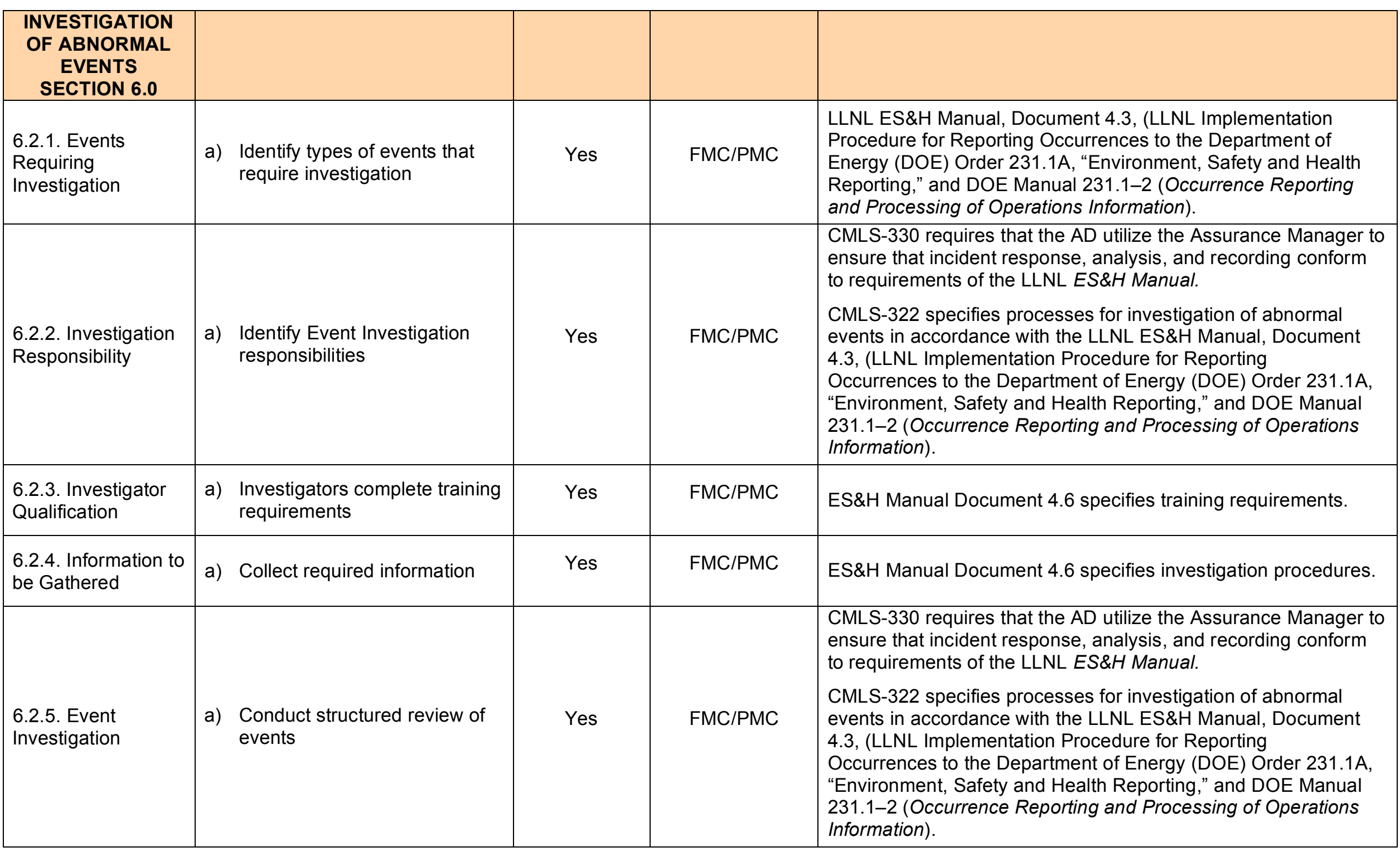




\section{Conduct of Operations Applicability Matrix}

\begin{tabular}{|c|c|c|c|c|c|}
\hline $\begin{array}{l}\text { 6.2.6. Investigative } \\
\text { Report }\end{array}$ & a) & Prepare investigative reports & Yes & FMC/PMC & $\begin{array}{l}\text { CMLS-330 requires that the AD utilize the Assurance Manager to } \\
\text { ensure that incident response, analysis, and recording conform } \\
\text { to requirements of the LLNL ES\&H Manual. } \\
\text { CMLS-322 specifies processes for investigation of abnormal } \\
\text { events in accordance with the LLNL ES\&H Manual, Document } \\
4.3 \text {, (LLNL Implementation Procedure for Reporting } \\
\text { Occurrences to the Department of Energy (DOE) Order 231.1A, } \\
\text { "Environment, Safety and Health Reporting," and DOE Manual } \\
231.1-2 \text { (Occurrence Reporting and Processing of Operations } \\
\text { Information). }\end{array}$ \\
\hline $\begin{array}{l}\text { 6.2.7. Event } \\
\text { Training }\end{array}$ & & $\begin{array}{l}\text { Evaluate events for training } \\
\text { benefit and conduct the } \\
\text { appropriate training }\end{array}$ & Yes & FMC/PMC & $\begin{array}{l}\text { Need for training is considered as part of the process described } \\
\text { in ES\&H Manual Document } 4.6\end{array}$ \\
\hline \multirow[t]{2}{*}{$\begin{array}{l}\text { 6.2.8. Event } \\
\text { Trending }\end{array}$} & & $\begin{array}{l}\text { Patterns of deficiencies should } \\
\text { be trended and a report } \\
\text { (causes and trends) provided } \\
\text { to the management chain. }\end{array}$ & Yes & PMC & $\begin{array}{l}\text { CMS-331 (Accident/Injury Prevention Program) defines } \\
\text { provisions for reviewing/analyzing safety data within the } \\
\text { Directorate. CMLS- } 305 \text { defines provisions for rolling up data to } \\
\text { the Institutional level for trending. } \\
\text { Trend analysis requirements are included in CMELS-305, } \\
\text { "ES\&H Self-Assessment Plan". }\end{array}$ \\
\hline & b) & $\begin{array}{l}\text { Information in the event } \\
\text { trending report should be } \\
\text { communicated to appropriate } \\
\text { facility personnel }\end{array}$ & Yes & PMC & Reports are provided to FMs per ES\&H Manual Document 4.1. \\
\hline 6.2.9. Sabotage & a) & $\begin{array}{l}\text { Response and investigative } \\
\text { procedures for suspected } \\
\text { sabotage should include the } \\
\text { guidance in Section 6.2.9. }\end{array}$ & Yes & FMC/PMC & $\begin{array}{l}\text { ES\&H Manual Documents } 4.5,4.6 \text { and } 4.7 \text { (Incidents - } \\
\text { Notification, Analysis, and Reporting; Incident Analysis Manual; } \\
\text { and ES\&H Analysis Methods) will be followed. CMLS-322 } \\
\text { (Occurrence Reporting Plan) specifies processes for } \\
\text { investigation of abnormal events. } \\
\text { ES\&H Manual, Document 22.1, Emergency Preparedness }\end{array}$ \\
\hline
\end{tabular}




\section{Conduct of Operations Applicability Matrix}

\begin{tabular}{|c|c|c|c|c|c|}
\hline $\begin{array}{l}\text { NOTIFICATIONS } \\
\text { SECTION } 7.0\end{array}$ & & & & & \\
\hline $\begin{array}{l}\text { 7.2.1. Notification } \\
\text { Procedures }\end{array}$ & & $\begin{array}{l}\text { Establish notification } \\
\text { procedures. }\end{array}$ & Yes & $\mathrm{FMC/PMC}$ & $\begin{array}{l}\text { All personnel working in CMELS facilities and personnel working } \\
\text { on CMELS activities in non-CMELS facilities and at offsite } \\
\text { locations are responsible to notify the Facility Point of Contact } \\
\text { (FPOC) and their division management of any unplanned events } \\
\text { or unexpected conditions that could potentially be reportable } \\
\text { (per CMLS-330 \& 322). } \\
\text { ES\&H Manual, Document 4.3, LLNL Implementation Procedure } \\
\text { for Reporting Occurrences to DOE }\end{array}$ \\
\hline $\begin{array}{l}\text { 7.2.2. Notification } \\
\text { Responsibility }\end{array}$ & & $\begin{array}{l}\text { Identify the individual (facility } \\
\text { management or program } \\
\text { management) responsible for } \\
\text { initiating the notification } \\
\text { process. }\end{array}$ & Yes & $\mathrm{FMC/PMC}$ & $\begin{array}{l}\text { CMS Site } 300 \text { Facility Emergency Self-Help Plan with attached } \\
\text { CMS Site } 300 \text { Employee Emergency Response Self-Help Guide } \\
\text { and CMLS-322 identify notification procedure and reporting } \\
\text { chains. } \\
\text { All CMELS operations managers (e.g. FMs, DDL/Ops, } \\
\text { DAD/Ops, etc.) are required to complete EM2010. Training } \\
\text { completions are documented in LTRAIN. } \\
\text { ES\&H Manual, Document 4.3, LLNL Implementation Procedure } \\
\text { for Reporting Occurrences to DOE }\end{array}$ \\
\hline $\begin{array}{l}\text { 7.2.3. Names and } \\
\text { Phone Numbers }\end{array}$ & a) & $\begin{array}{l}\text { Contact information for } \\
\text { occurrence reporting is made } \\
\text { available. }\end{array}$ & Yes & $\mathrm{FMC/PMC}$ & $\begin{array}{l}\text { CMS Site } 300 \text { Facility Emergency Self-Help Plan with attached } \\
\text { CMS Site } 300 \text { Employee Emergency Response Self-Help Guide } \\
\text { and CMLS-322 identify notification procedure and reporting } \\
\text { chains, which includes notification of the Assurance Manager. }\end{array}$ \\
\hline $\begin{array}{l}\text { 7.2.4. } \\
\text { Documentation }\end{array}$ & a) & $\begin{array}{l}\text { Maintain a formal record of } \\
\text { notifications. }\end{array}$ & Yes & $\mathrm{FMC/PMC}$ & $\begin{array}{l}\text { CMS Site } 300 \text { Facility Emergency Self-Help Plan with attached } \\
\text { CMS Site } 300 \text { Employee Emergency Response Self-Help Guide } \\
\text { and CMLS-322 identify notification procedure and reporting } \\
\text { chains. } \\
\text { All CMELS operations managers (e.g. FMs, DDL/Ops, } \\
\text { DAD/Ops, etc.) are required to complete EM2010. Training } \\
\text { completions are documented in LTRAIN. } \\
\text { ES\&H Manual, Document 4.3, LLNL Implementation Procedure } \\
\text { for Reporting Occurrences to DOE. Formal records of ORPS } \\
\text { notifications are maintained by the Institutional Occurrence } \\
\text { Reporting Manager. }\end{array}$ \\
\hline
\end{tabular}




\section{Conduct of Operations Applicability Matrix}

\begin{tabular}{|c|c|c|c|c|c|}
\hline $\begin{array}{l}\text { 7.2.5. } \\
\text { Communication } \\
\text { Equipment }\end{array}$ & & $\begin{array}{l}\text { Maintain communication } \\
\text { equipment adequate for } \\
\text { notification procedure. }\end{array}$ & Yes & FMC/PMC & Communication equipment is maintained by the Institution. \\
\hline \multicolumn{6}{|l|}{$\begin{array}{l}\text { CONTROL OF } \\
\text { EQUIPMENT AND } \\
\text { SYSTEMS } \\
\text { STATUS } \\
\text { SECTION } 8.0 \\
\end{array}$} \\
\hline \multirow[t]{3}{*}{$\begin{array}{l}\text { 8.2.1. Status } \\
\text { Change } \\
\text { Authorization and } \\
\text { Reporting }\end{array}$} & a) & $\begin{array}{l}\text { Identify equipment and/or } \\
\text { systems whose configuration } \\
\text { must be maintained. }\end{array}$ & Yes & $\mathrm{FMC} / \mathrm{PMC}$ & $\begin{array}{l}\text { FSPs identify building safety systems (under Plant Engineering } \\
\text { configuration management) and building safety features (under } \\
\text { CMELS configuration management). Activity specific controls } \\
\text { are identified through the IWS and/or IWS/SP and may require } \\
\text { activity-level QA plans in accordance with CMLS-901 (Quality } \\
\text { Assurance Plan). CMLS-405 (Configuration Management Plan) } \\
\text { establishes and maintains a level of Configuration Management } \\
\text { (CM) control for facilities managed by CMELS. } \\
\text { ES\&H Manual, Document 41.2, "Configuration Management } \\
\text { Program Description," }\end{array}$ \\
\hline & b) & $\begin{array}{l}\text { Establish a formal mechanism } \\
\text { to authorize changes in } \\
\text { configuration or status. }\end{array}$ & Yes & $\mathrm{FMC} / \mathrm{PMC}$ & $\begin{array}{l}\text { An IWS is required for all modifications to CMELS facilities. } \\
\text { Facility Point of Contact concurrence is required on all IWSs and } \\
\text { Plant Engineering "bridging documents" that would modify a } \\
\text { CMELS facility. CMLS- } 405 \text { documents the requirements that } \\
\text { must be followed for modifications to all items under CM. When } \\
\text { required, an Explosives Work Permit is used in the authorization } \\
\text { process. }\end{array}$ \\
\hline & c) & $\begin{array}{l}\text { Establish a formal mechanism } \\
\text { to ensure personnel are kept } \\
\text { informed of any changes in the } \\
\text { operational status of the } \\
\text { equipment or systems. }\end{array}$ & Yes & $\mathrm{FMC} / \mathrm{PMC}$ & $\begin{array}{l}\text { The IWS process informs of proposed changes. Prior to the } \\
\text { initiation of those facility-related changes, the FPOCs contact } \\
\text { affected building personnel. For changes to programmatic } \\
\text { equipment, the RI contacts those personnel who will be } \\
\text { affected. }\end{array}$ \\
\hline $\begin{array}{l}\text { 8.2.2. Equipment } \\
\text { and System } \\
\text { Alignment }\end{array}$ & a) & $\begin{array}{l}\text { Equipment and systems are } \\
\text { aligned or checked for proper } \\
\text { alignment before operation. }\end{array}$ & Yes & $\mathrm{FMC} / \mathrm{PMC}$ & $\begin{array}{l}\text { CMLS-330 discusses the work authorization process. The IWS } \\
\text { process includes a pre-start review to ensure everything is } \\
\text { ready to go. A pre-start checklist can be used to help in this } \\
\text { review. The formality of a pre-start review when required is } \\
\text { determined by the Work Activity Level and the scope of the } \\
\text { work. }\end{array}$ \\
\hline
\end{tabular}




\section{Conduct of Operations Applicability Matrix}

\begin{tabular}{|c|c|c|c|c|c|}
\hline $\begin{array}{l}\text { 8.2.3. Equipment } \\
\text { Locking and } \\
\text { Tagging }\end{array}$ & a) & $\begin{array}{l}\text { Lockout and tagout } \\
\text { procedures are in place. }\end{array}$ & Yes & $\mathrm{FMC/PMC}$ & $\begin{array}{l}\text { Lockout and tagout is implemented through the IWS process in } \\
\text { accordance with Document } 12.6 \text { of the LLNL ES\&H Manual. } \\
\text { CMELS Facility Operations personnel do not perform lockout \& } \\
\text { tag. }\end{array}$ \\
\hline $\begin{array}{l}\text { 8.2.4. Operational } \\
\text { Limits Compliance }\end{array}$ & a) & $\begin{array}{l}\text { Establish administrative } \\
\text { controls that document } \\
\text { compliance with operating } \\
\text { limits. }\end{array}$ & Yes & $\mathrm{FMC/PMC}$ & $\begin{array}{l}\text { Facility concurrence on work to be conducted as documented in } \\
\text { an IWS, as described in CMLS- } 330 \text { and ES\&H Manual } \\
\text { Document } 2.1 \text {, is provided to ensure the activity is within the } \\
\text { safety basis envelope of a facility. } \\
\text { Authorizing Individuals monitor the work to ensure that hazards } \\
\text { are identified, controls are developed and implemented, and that } \\
\text { ES\&H requirements are met. Where required, equipment run } \\
\text { logs document that operating limits are observed, that critical } \\
\text { measurement and test equipment is operational, and that } \\
\text { routine maintenance and calibrations are conducted. }\end{array}$ \\
\hline $\begin{array}{l}\text { 8.2.5. Equipment } \\
\text { Deficiency } \\
\text { Identification and } \\
\text { Documentation }\end{array}$ & a) & $\begin{array}{l}\text { Establish method for } \\
\text { identifying, reporting, and } \\
\text { documenting equipment } \\
\text { deficiencies. }\end{array}$ & Yes & $\mathrm{FMC/PMC}$ & $\begin{array}{l}\text { CMLS-305, CMS-306 (Deficiency Tracking Management Plan) } \\
\text { and CMLS-322 (Occurrence Reporting Plan) define processes } \\
\text { to regularly self assess operations, facilities, activities and to } \\
\text { report deficiencies. Other feedback and improvement } \\
\text { techniques are defined in CMLS-330. Scheduled } \\
\text { inspections/self-assessments are used in addition to employee } \\
\text { reports and may initiate ITS deficiencies. Suspect Counterfeit } \\
\text { Inspections are performed every three years. } \\
\text { ES\&H Manual, Document 4.2, "ES\&H Issues and Deficiencies } \\
\text { Management }\end{array}$ \\
\hline $\begin{array}{l}\text { 8.2.6. Work } \\
\text { Authorization and } \\
\text { Documentation }\end{array}$ & & $\begin{array}{l}\text { Written authorization should } \\
\text { be obtained for all shift } \\
\text { activities (including } \\
\text { modifications or maintenance) } \\
\text { on equipment or systems } \\
\text { important to safety, that affects } \\
\text { operations, or that changes } \\
\text { control indications or alarms. }\end{array}$ & Yes & $\mathrm{FMC/PMC}$ & $\begin{array}{l}\text { Work on SSCs is performed under an authorized IWS in } \\
\text { accordance with CMLS-405 (Directorate Configuration } \\
\text { Management Plan). } \\
\text { ES\&H Manual, Document 2.1, "General Worker Responsibilities } \\
\text { and Integrated Safety Management ", and Document 2.2, } \\
\text { "Managing ES\&H for LLNL Work" }\end{array}$ \\
\hline
\end{tabular}




\section{Conduct of Operations Applicability Matrix}

\begin{tabular}{|c|c|c|c|c|c|}
\hline $\begin{array}{l}\text { 8.2.7. Equipment } \\
\text { Post-Maintenance } \\
\text { Testing and Return } \\
\text { to Service }\end{array}$ & & $\begin{array}{l}\text { Establish post- } \\
\text { modification/maintenance } \\
\text { testing procedures for } \\
\text { equipment or systems } \\
\text { important to safety. }\end{array}$ & Yes & FMC/PMC & $\begin{array}{l}\text { Plant Engineering maintains configuration management of } \\
\text { required building safety systems and identifies post } \\
\text { maintenance testing requirements. Configuration management } \\
\text { on other building safety features is the responsibility of the } \\
\text { CMELS ADFM as per CMLS- } 405 \text {. Configuration management } \\
\text { on activity-specific safety equipment (interlocks, etc) is the } \\
\text { responsibility of the RI. }\end{array}$ \\
\hline 8.2.8. Alarm Status & a) & $\begin{array}{l}\text { Ensure there is a clear } \\
\text { indication/understanding of } \\
\text { alarm status. }\end{array}$ & Yes & FMC/PMC & $\begin{array}{l}\text { CMELS FSPs discuss building alarms. Activity-specific alarms } \\
\text { are defined in applicable IWS/SPs. LLNL ES\&H Manual; } \\
\text { Document } 12.1 \text { defines process for alarm systems. }\end{array}$ \\
\hline $\begin{array}{l}\text { 8.2.9. Temporary } \\
\text { Modification Control }\end{array}$ & a) & $\begin{array}{l}\text { Establish control for installing } \\
\text { temporary modifications to } \\
\text { SSCs under configuration } \\
\text { management. }\end{array}$ & Yes & FMC/PMC & $\begin{array}{l}\text { Modifications to building safety systems require an IWS with } \\
\text { facility concurrence. } \\
\text { ES\&H Manual, Document } 51.3 \\
\text { ES\&H Manual, Document } 3.1 \\
\text { ES\&H Manual, Document } 12.1\end{array}$ \\
\hline $\begin{array}{l}\text { 8.2.10. Distribution } \\
\text { and Control of } \\
\text { Equipment and } \\
\text { System Document }\end{array}$ & a) & $\begin{array}{l}\text { Establish system for document } \\
\text { control and distribution for } \\
\text { equipment or systems under } \\
\text { configuration management. }\end{array}$ & Yes & FMC/PMC & $\begin{array}{l}\text { The IWS system maintains control of the IWS documents. } \\
\text { CMLS-904 (Control of Unclassified Management Documents) } \\
\text { contains CMELS guidance on document control. }\end{array}$ \\
\hline \multicolumn{6}{|l|}{$\begin{array}{l}\text { LOCKOUTS AND } \\
\text { TAGOUTS } \\
\text { SECTION } 9.0\end{array}$} \\
\hline $\begin{array}{l}9.2 .1 . \\
\text { Lockout/Tagout } \\
\text { Use }\end{array}$ & a) & $\begin{array}{l}\text { Work supervisors of LLNL and } \\
\text { subcontract workers shall } \\
\text { satisfy LLNL's lockout and tag } \\
\text { program requirements } \\
\text { described in Document } 12.6 .\end{array}$ & Yes & FMC/PMC & $\begin{array}{l}\text { Lockout and tagout is implemented through the IWS process in } \\
\text { accordance with Document } 12.6 \text { of the LLNL ES\&H Manual. }\end{array}$ \\
\hline $\begin{array}{l}\text { 9.2.2. Lockout and } \\
\text { Tagout } \\
\text { Implementation }\end{array}$ & a) & $\begin{array}{l}\text { Lockout/Tagout } \\
\text { implementation shall be in } \\
\text { accordance with Document } \\
12.6 \text {. }\end{array}$ & Yes & FMC/PMC & $\begin{array}{l}\text { Lockout and tagout is implemented through the IWS process in } \\
\text { accordance with Document } 12.6 \text { of the LLNL ES\&H Manual. }\end{array}$ \\
\hline
\end{tabular}




\section{Conduct of Operations Applicability Matrix}

\begin{tabular}{|c|c|c|c|c|c|}
\hline & & $\begin{array}{l}\text { When appropriate, lockout and } \\
\text { tag requirements are } \\
\text { incorporated into (or } \\
\text { referenced in) FSPs, } \\
\text { IWS/SPs, or SOPs. }\end{array}$ & Yes & FMC/PMC & ES\&H Manual, Document 12.6, LLNL Lockout/Tagout Program \\
\hline $\begin{array}{l}\text { 9.2.3. Protective } \\
\text { Materials and } \\
\text { Hardware }\end{array}$ & a) & $\begin{array}{l}\text { Adequate protective materials } \\
\text { and hardware for lockout and } \\
\text { tagout are provided. }\end{array}$ & Yes & FMC/PMC & ES\&H Manual, Document 12.6, LLNL Lockout/Tagout Program \\
\hline $\begin{array}{l}9.2 .4 . \\
\text { Lockout/Tagout } \\
\text { Program }\end{array}$ & a) & $\begin{array}{l}\text { A lockout/tagout program has } \\
\text { been established. }\end{array}$ & Yes & FMC/PMC & $\begin{array}{l}\text { Lockout and tagout is implemented through the IWS process in } \\
\text { accordance with Document } 12.6 \text { of the LLNL ES\&H Manual. }\end{array}$ \\
\hline $\begin{array}{l}\text { 9.2.5. Procedures } \\
\text { for Lockout/Tagout }\end{array}$ & a) & $\begin{array}{l}\text { Lockout/tagout procedures are } \\
\text { developed, documented, } \\
\text { validated, and utilized. }\end{array}$ & Yes & FMC/PMC & ES\&H Manual, Document 12.6, LLNL Lockout/Tagout Program \\
\hline $\begin{array}{l}\text { 9.2.6. Application of } \\
\text { Lockout/Tagout }\end{array}$ & a) & $\begin{array}{l}\text { Established lockout/tagout } \\
\text { procedures cover the } \\
\text { elements and actions } \\
\text { described in Section } 9.2 .6 \text { and } \\
\text { Document 12.6. }\end{array}$ & Yes & FMC/PMC & ES\&H Manual, Document 12.6, LLNL Lockout/Tagout Program \\
\hline $\begin{array}{l}\text { 9.2.7. Testing or } \\
\text { Positioning of } \\
\text { Equipment or } \\
\text { Components }\end{array}$ & a) & $\begin{array}{l}\text { For temporary removal of } \\
\text { Lockout/Tagout devices, } \\
\text { follow the actions described in } \\
\text { Section } 9.2 .7 \text {. }\end{array}$ & Yes & FMC/PMC & ES\&H Manual, Document 12.6, LLNL Lockout/Tagout Program \\
\hline $\begin{array}{l}\text { 9.2.8. Periodic } \\
\text { Inspections }\end{array}$ & a) & $\begin{array}{l}\text { Conduct periodic inspections } \\
\text { to determine adequacy of } \\
\text { lockout/tagout program, as } \\
\text { described in Document 12.6. }\end{array}$ & Yes & FMC/PMC & $\begin{array}{l}\text { Lockout and tagout is implemented through the IWS process in } \\
\text { accordance with Document } 12.6 \text { of the LLNL ES\&H Manual. }\end{array}$ \\
\hline 9.2.9. Caution Tags & a) & $\begin{array}{l}\text { Use of caution tags should } \\
\text { follow protocol described in } \\
\text { Section } 9.2 .9 \text { and as } \\
\text { described in Document 12.6. }\end{array}$ & Yes & FMC/PMC & ES\&H Manual, Document 12.6, LLNL Lockout/Tagout Program \\
\hline $\begin{array}{l}\text { 9.2.10. Training } \\
\text { and Communication }\end{array}$ & a) & $\begin{array}{l}\text { Personnel shall have training } \\
\text { consistent with Section 9.2.10. }\end{array}$ & Yes & FMC/PMC & ES\&H Manual, Document 12.6, LLNL Lockout/Tagout Program \\
\hline
\end{tabular}




\section{Conduct of Operations Applicability Matrix}

\begin{tabular}{|c|c|c|c|c|c|}
\hline $\begin{array}{l}\text { 9.2.11. Lockout or } \\
\text { Tagout } \\
\text { Implementation }\end{array}$ & & $\begin{array}{l}\text { Only authorized, qualified } \\
\text { personnel accomplish } \\
\text { lockout/tagout, as described in } \\
\text { Document } 12.6 \text {. }\end{array}$ & Yes & FMC/PMC & ES\&H Manual, Document 12.6, LLNL Lockout/Tagout Program \\
\hline $\begin{array}{l}\text { 9.2.12. Notification } \\
\text { of Personnel }\end{array}$ & a) & $\begin{array}{l}\text { Personnel affected by the } \\
\text { lockout/tagout application or } \\
\text { removal are notified, as } \\
\text { described in Document } 12.6 \text {. }\end{array}$ & Yes & $\mathrm{FMC} / \mathrm{PMC}$ & ES\&H Manual, Document 12.6, LLNL Lockout/Tagout Program \\
\hline $\begin{array}{l}\text { 9.2.13. Outside } \\
\text { Contractors }\end{array}$ & a) & $\begin{array}{l}\text { Outside contractors adhere to } \\
\text { lockout/tagout procedures as } \\
\text { described in Document } 12.6 \text {. }\end{array}$ & Yes & $\mathrm{FMC} / \mathrm{PMC}$ & ES\&H Manual, Document 12.6, LLNL Lockout/Tagout Program \\
\hline $\begin{array}{l}\text { 9.2.14. Group } \\
\text { Lockouts or } \\
\text { Tagouts }\end{array}$ & a) & $\begin{array}{l}\text { Adhere to group } \\
\text { lockout/tagouts procedures as } \\
\text { described in Document } 12.6 \text {. }\end{array}$ & Yes & FMC/PMC & ES\&H Manual, Document 12.6, LLNL Lockout/Tagout Program \\
\hline $\begin{array}{l}\text { 9.2.15. Shift or } \\
\text { Personnel Changes }\end{array}$ & a) & $\begin{array}{l}\text { Adhere to procedures for } \\
\text { transferring locks and tags } \\
\text { when personnel or shifts } \\
\text { change, as described in } \\
\text { Document } 12.6 \text {. }\end{array}$ & Yes & FMC/PMC & ES\&H Manual, Document 12.6, LLNL Lockout/Tagout Program \\
\hline \multicolumn{6}{|l|}{$\begin{array}{l}\text { INDEPENDENT } \\
\text { VERIFICATION } \\
\text { SECTION } 10.0\end{array}$} \\
\hline $\begin{array}{l}\text { 10.2.1. } \\
\text { Components } \\
\text { Requiring } \\
\text { Independent } \\
\text { Verification }\end{array}$ & a) & $\begin{array}{l}\text { Identify components/systems } \\
\text { requiring independent } \\
\text { verification whose improper } \\
\text { positioning could result in an } \\
\text { impact to health, safety, the } \\
\text { environment, or significant } \\
\text { impact to programs. }\end{array}$ & Yes & FMC/PMC & $\begin{array}{l}\text { Critical common facility and institutional equipment and systems } \\
\text { capable of significant impact to ES\&H or the programs are } \\
\text { identified in the FSP as Building Safety Systems whose proper } \\
\text { function is verified by other organizations. Facility safety features } \\
\text { are identified in the FSP, and are managed in accordance with } \\
\text { CMLS- } 405 \text {. } \\
\text { Critical programmatic equipment and systems capable of } \\
\text { significant impacts to ES\&H or programs and requiring } \\
\text { independent verification are identified in IWS/SPs or operating } \\
\text { procedures. } \\
\text { Critical facility and programmatic equipment employ interlocks } \\
\text { and alarms to verify proper operation. Independent verification is } \\
\text { not required. Interlocks are verified quarterly. }\end{array}$ \\
\hline
\end{tabular}




\section{Conduct of Operations Applicability Matrix}

\begin{tabular}{|c|c|c|c|c|c|}
\hline $\begin{array}{l}\text { 10.2.2. Occasions } \\
\text { Requiring } \\
\text { Independent } \\
\text { Verification }\end{array}$ & a) & $\begin{array}{l}\text { Ensure that independent } \\
\text { verification is conducted and } \\
\text { documented following the } \\
\text { guidance in Section 10.2.2. }\end{array}$ & Yes & $\mathrm{FMC} / \mathrm{PMC}$ & $\begin{array}{l}\text { Interlock checks are documented quarterly } \\
\text { Prestart reviews verify that all systems are functional and ready } \\
\text { to go and documented as part of the IWS process. }\end{array}$ \\
\hline $\begin{array}{l}\text { 10.2.3. Verification } \\
\text { Techniques }\end{array}$ & a) & $\begin{array}{l}\text { Ensure that verification } \\
\text { techniques are followed using } \\
\text { the guidance in Section } \\
10.2 .3 \text {. }\end{array}$ & Yes & $\mathrm{FMC/PMC}$ & Verification follows the guidance in Section 10.2.3 \\
\hline \multicolumn{6}{|l|}{$\begin{array}{l}\text { LOGKEEPING } \\
\text { SECTION } 11.0\end{array}$} \\
\hline $\begin{array}{l}\text { 11.2.1. } \\
\text { Establishment of } \\
\text { Operating Logs }\end{array}$ & a) & $\begin{array}{l}\text { Identify operations, areas, or } \\
\text { equipment where formal } \\
\text { record-keeping is required, } \\
\text { and assign logbook-keeping } \\
\text { responsibilities. }\end{array}$ & Yes & $\mathrm{FMC/PMC}$ & $\begin{array}{l}\text { Some programs may require logbooks as part of their QA } \\
\text { program. These logbooks are managed per the requirements in } \\
\text { the respective ALQAP. } \\
\text { Logbooks are required for cranes, facility-related oxygen } \\
\text { deficiency monitors, forklift operations, explosive inventories, } \\
\text { radiation area monitors, and emergency eyewash/shower testing } \\
\text { in CMELS facilities. } \\
\text { Site } 300 \text { Explosives Waste Storage Facility (EWSF) and } \\
\text { Explosives Waste Treatment Facility (EWTF) permits require that } \\
\text { logbooks be maintained. } \\
\text { Logbooks are required for pressing, drying, and radiography } \\
\text { operations, and for quarterly interlock checks at Site } 300 \text {. }\end{array}$ \\
\hline $\begin{array}{l}\text { 11.2.2. Timeliness } \\
\text { of Recordings }\end{array}$ & a) & $\begin{array}{l}\text { Ensure information is added in } \\
\text { a timely manner. }\end{array}$ & Yes & $\mathrm{FMC/PMC}$ & $\begin{array}{l}\text { Some programs may require logbooks as part of their QA } \\
\text { program. These logbooks are managed per the requirements in } \\
\text { the respective ALQAP. } \\
\text { Logbooks for cranes, oxygen deficiency monitors, forklifts, and } \\
\text { emergency eyewash/showers, pressing, drying, and radiography } \\
\text { operations, and for quarterly interlock checks will be completed } \\
\text { in accordance with the requirements listed in the applicable } \\
\text { ES\&H Manual sections and CMLS-305. } \\
\text { Site } 300 \text { Explosives Waste Storage Facility (EWSF) and } \\
\text { Explosives Waste Treatment Facility (EWTF) logbooks are } \\
\text { managed per the permit requirements. }\end{array}$ \\
\hline
\end{tabular}




\section{Conduct of Operations Applicability Matrix}

\begin{tabular}{|c|c|c|c|c|c|}
\hline $\begin{array}{l}\text { 11.2.3. Information } \\
\text { to be Recorded }\end{array}$ & & $\begin{array}{l}\text { Specify the type of information } \\
\text { to be entered in the logbook, } \\
\text { using the guidance in Section } \\
11.2 .3 \text {. }\end{array}$ & Yes & FMC/PMC & $\begin{array}{l}\text { Logbooks are kept in each process facility and include } \\
\text { information as specified in the facility or process operating } \\
\text { procedure. } \\
\text { Some programs may require logbooks as part of their QA } \\
\text { program. These logbooks are managed per the requirements in } \\
\text { the respective ALQAP. } \\
\text { Logbooks for cranes, oxygen deficiency monitors, forklifts, and } \\
\text { emergency eyewash/showers, pressing, drying, and radiography } \\
\text { operations, and for quarterly interlock checks will be completed } \\
\text { in accordance with the requirements listed in the applicable } \\
\text { ES\&H Manual sections. } \\
\text { Site } 300 \text { Explosives Waste Storage Facility (EWSF) and } \\
\text { Explosives Waste Treatment Facility (EWTF) logbooks are } \\
\text { managed per the permit requirements. }\end{array}$ \\
\hline 11.2.4. Legibility & a) & $\begin{array}{l}\text { Logbook entries should be } \\
\text { made in a legible and easily } \\
\text { understood manner. }\end{array}$ & Yes & FMC/PMC & $\begin{array}{l}\text { Some programs may require logbooks as part of their QA } \\
\text { program. These logbooks are managed per the requirements in } \\
\text { the respective ALQAP. } \\
\text { Site } 300 \text { Explosives Waste Storage Facility (EWSF) and } \\
\text { Explosives Waste Treatment Facility (EWTF) permits require } \\
\text { that logbooks be maintained. The permits contain specific } \\
\text { requirements for legible entries in all logbooks. Logbooks are } \\
\text { periodically reviewed and signed by the Facility Manager. }\end{array}$ \\
\hline 11.2.5. Corrections & & $\begin{array}{l}\text { Follow Section } 11.2 .5 \text { for } \\
\text { correcting erroneous entries. }\end{array}$ & Yes & FMC/PMC & $\begin{array}{l}\text { Some programs may require logbooks as part of their QA } \\
\text { program. These logbooks are managed per the requirements in } \\
\text { the respective ALQAP. } \\
\text { Site } 300 \text { Explosives Waste Storage Facility (EWSF) and } \\
\text { Explosives Waste Treatment Facility (EWTF) permits require } \\
\text { that logbooks be maintained. The permits contain specific } \\
\text { requirements for correcting erroneous entries by drawing a } \\
\text { single line through the incorrect information, entering, initialing } \\
\text { and dating the correct information. Logbooks are periodically } \\
\text { reviewed and signed by the Facility Manager. }\end{array}$ \\
\hline
\end{tabular}




\section{Conduct of Operations Applicability Matrix}

\begin{tabular}{|c|c|c|c|c|}
\hline 11.2.6. Log Review & $\begin{array}{l}\text { a) Regularly review the logbook } \\
\text { for conformance with logbook- } \\
\text { keeping requirements. }\end{array}$ & Yes & FMC/PMC & $\begin{array}{l}\text { Some programs may require logbooks as part of their QA } \\
\text { program. These logbooks are managed per the requirements in } \\
\text { the respective ALQAP. } \\
\text { Work supervisors directly responsible for logbook entries } \\
\text { regarding cranes, oxygen deficiency monitors, forklifts, } \\
\text { eyewashes and showers, pressing, drying, and radiography } \\
\text { operations, and for quarterly interlock check work areas will } \\
\text { regularly review logbooks in their areas during informal self- } \\
\text { assessments to check for conformance with logbook-keeping } \\
\text { requirements and to spot trends that may indicate degrading } \\
\text { operations so that corrective action can be taken before an } \\
\text { emergency occurs. } \\
\text { Site } 300 \text { Explosives Waste Storage Facility (EWSF) and } \\
\text { Explosives Waste Treatment Facility (EWTF) permits require } \\
\text { that logbooks be maintained. The permits contain specific } \\
\text { requirements for periodic reviews of all logbooks. Logbooks are } \\
\text { periodically reviewed and signed by the Facility Manager. }\end{array}$ \\
\hline $\begin{array}{l}\text { 11.2.7. Care and } \\
\text { Keeping of Logs }\end{array}$ & $\begin{array}{l}\text { a) Maintain logbooks in a } \\
\text { retrievable manner. }\end{array}$ & Yes & FMC/PMC & $\begin{array}{l}\text { Some programs may require logbooks as part of their QA } \\
\text { program. These logbooks are managed per the requirements in } \\
\text { the respective ALQAP. } \\
\text { Logbooks for cranes, oxygen deficiency monitors, forklifts, } \\
\text { eyewashes and showers, pressing, drying, and radiography } \\
\text { operations, and for quarterly interlock checks will be protected } \\
\text { from fire, water, or other types of damage. } \\
\text { Completed logbooks will be retained in a retrievable manner for } \\
\text { time periods specified by the facility manager or program. } \\
\text { Site } 300 \text { Explosives Waste Storage Facility (EWSF) and } \\
\text { Explosives Waste Treatment Facility (EWTF) permits require } \\
\text { that logbooks be maintained. The permits contain specific } \\
\text { requirements for maintaining the logbooks. Logbooks are } \\
\text { maintained in Facility files. }\end{array}$ \\
\hline \multicolumn{5}{|l|}{$\begin{array}{l}\text { OPERATIONS } \\
\text { TURNOVER } \\
\text { SECTION } 12.0\end{array}$} \\
\hline $\begin{array}{l}\text { 12.2.1. Turnover } \\
\text { Checklists }\end{array}$ & $\begin{array}{l}\text { a) Identify personnel (by } \\
\text { position), that require a shift } \\
\text { turnover checklist. }\end{array}$ & No & NA & Shifts are not utilized in CMELS S300 facilities \\
\hline
\end{tabular}




\section{Conduct of Operations Applicability Matrix}

\begin{tabular}{|c|c|c|c|c|c|}
\hline & & $\begin{array}{l}\text { Develop shift turnover } \\
\text { checklist(s). }\end{array}$ & No & NA & Shifts are not utilized in CMELS S300 facilities \\
\hline $\begin{array}{l}\text { 12.2.2. Document } \\
\text { Review }\end{array}$ & a) & $\begin{array}{l}\text { Oncoming operators and } \\
\text { supervisors review documents } \\
\text { specified on their checklists. }\end{array}$ & No & NA & Shifts are not utilized in CMELS S300 facilities \\
\hline $\begin{array}{l}\text { 12.2.3. Control } \\
\text { Panel Walkdown }\end{array}$ & a) & $\begin{array}{l}\text { Conduct control panel } \\
\text { walkdowns as appropriate. }\end{array}$ & No & NA & Shifts are not utilized in CMELS S300 facilities \\
\hline $\begin{array}{l}\text { 12.2.4. Discussion } \\
\text { and Exchange of } \\
\text { Responsibility }\end{array}$ & a) & $\begin{array}{l}\text { Conduct discussion and } \\
\text { exchange of responsibility at } \\
\text { shift change. }\end{array}$ & No & NA & Shifts are not utilized in CMELS S300 facilities \\
\hline $\begin{array}{l}\text { 12.2.5. Shift Crew } \\
\text { Briefing }\end{array}$ & a) & $\begin{array}{l}\text { Operations supervisors } \\
\text { conduct crew briefing as } \\
\text { required. }\end{array}$ & No & NA & Shifts are not utilized in CMELS S300 facilities \\
\hline $\begin{array}{l}\text { 12.2.6. Reliefs } \\
\text { Occurring During } \\
\text { the Shift }\end{array}$ & a) & $\begin{array}{l}\text { Specify and document shift } \\
\text { turnover responsibilities. }\end{array}$ & No & NA & Shifts are not utilized in CMELS S300 facilities \\
\hline \multicolumn{6}{|l|}{$\begin{array}{c}\text { OPERATIONS } \\
\text { ASPECTS OF } \\
\text { FACILITY } \\
\text { CHEMISTRY AND } \\
\text { UNIQUE } \\
\text { PROCESSES } \\
\text { SECTION } 13.0 \\
\end{array}$} \\
\hline $\begin{array}{l}\text { 13.2.1. Operator } \\
\text { Responsibilities }\end{array}$ & & $\begin{array}{l}\text { Identify the samples requiring } \\
\text { analysis and analysis to be } \\
\text { performed, and define the } \\
\text { range of acceptable results. }\end{array}$ & Yes & PMC & $\begin{array}{l}\text { There are no routine programmatic or facility-related sampling } \\
\text { and analyzing efforts of operating parameters. Some } \\
\text { institutionally required chemical analysis to protect ES\&H is } \\
\text { performed by EPD and the ES\&H Team. } \\
\text { Some operations (e.g. scale-up synthesis of a new HE) will } \\
\text { require sampling and analysis. This sampling, analysis and } \\
\text { acceptability of results is documented in a Peer Review. } \\
\text { Some sampling will be performed in the Forensics Receival } \\
\text { Facility. }\end{array}$ \\
\hline
\end{tabular}




\section{Conduct of Operations Applicability Matrix}

\begin{tabular}{|c|c|c|c|c|c|}
\hline & & $\begin{array}{l}\text { Ensure that workers involved } \\
\text { in sampling and analyses } \\
\text { understand their } \\
\text { responsibilities. }\end{array}$ & Yes & PMC & $\begin{array}{l}\text { The IWSs (with associated Peer review if applicable) and FSPs } \\
\text { that control these activities detail the workers responsibilities. }\end{array}$ \\
\hline $\begin{array}{l}\text { 13.2.2. Operator } \\
\text { Knowledge }\end{array}$ & a) & $\begin{array}{l}\text { Ensure workers have the } \\
\text { necessary training and } \\
\text { equipment to carry out their } \\
\text { specified tasks. }\end{array}$ & Yes & PMC & $\begin{array}{l}\text { The IWSs (with associated Peer review if applicable) and FSPs } \\
\text { that control these activities detail the training and equipment } \\
\text { requirements. }\end{array}$ \\
\hline $\begin{array}{l}\text { 13.2.3. Operator } \\
\text { Response to } \\
\text { Process Problems }\end{array}$ & a) & $\begin{array}{l}\text { Respond to out-of-range } \\
\text { results or process parameters. }\end{array}$ & Yes & PMC & $\begin{array}{l}\text { The IWSs (with associated Peer review if applicable) and FSPs } \\
\text { that control these activities detail the out-of-range response. }\end{array}$ \\
\hline $\begin{array}{l}\text { 13.2.4. } \\
\text { Communication } \\
\text { Between } \\
\text { Operations and } \\
\text { Process Personnel }\end{array}$ & a) & $\begin{array}{l}\text { Maintain communication } \\
\text { between operations and } \\
\text { process personnel. }\end{array}$ & Yes & $\mathrm{FMC} / \mathrm{PMC}$ & Personnel are in two way communication \\
\hline \multicolumn{6}{|l|}{$\begin{array}{l}\text { REQUIRED } \\
\text { READING } \\
\text { SECTION } 14.0\end{array}$} \\
\hline 14.2.1. File Index & a) & $\begin{array}{l}\text { Identify documents to be } \\
\text { included in each facility's } \\
\text { required reading program. }\end{array}$ & Yes & $\mathrm{FMC} / \mathrm{PMC}$ & $\begin{array}{l}\text { FSPs are the only facility-level document identified as required } \\
\text { reading; all residents must read the sections applicable to their } \\
\text { work. Workers are required to read the IWSs for their work. } \\
\text { Each IWS identifies any supplemental required reading for each } \\
\text { activity (e.g. SP, Hazard Assessment and Control, Engineering } \\
\text { Safety Note, etc.). }\end{array}$ \\
\hline \multirow[t]{2}{*}{$\begin{array}{l}\text { 14.2.2. Reading } \\
\text { Assignments }\end{array}$} & a) & $\begin{array}{l}\text { Identify which documents must } \\
\text { be read by individuals (by } \\
\text { position). }\end{array}$ & Yes & $\mathrm{FMC} / \mathrm{PMC}$ & $\begin{array}{l}\text { FSPs are the only facility-level document identified as required } \\
\text { reading. Workers are required to read the IWSs for their work. } \\
\text { Each IWS identifies any supplemental required reading for each } \\
\text { activity (e.g. SP, Hazard Assessment and Control, Engineering } \\
\text { Safety Note, etc.). }\end{array}$ \\
\hline & b) & $\begin{array}{l}\text { Required reading documents } \\
\text { should be available in the } \\
\text { facility or in the program area. }\end{array}$ & Yes & $\mathrm{FMC} / \mathrm{PMC}$ & $\begin{array}{l}\text { Documents identified in the IWSs are either uploaded to the } \\
\text { IWS or are maintained by the RI for that activity. }\end{array}$ \\
\hline
\end{tabular}




\section{Conduct of Operations Applicability Matrix}

\begin{tabular}{|c|c|c|c|c|c|}
\hline $\begin{array}{l}\text { 14.2.3. Required } \\
\text { Dates for } \\
\text { Completion of } \\
\text { Reading }\end{array}$ & a) & $\begin{array}{l}\text { Designate completion dates } \\
\text { for required reading. }\end{array}$ & Yes & $\mathrm{FMC} / \mathrm{PMC}$ & $\begin{array}{l}\text { The CMELS Site } 300 \text { Facility manager maintains records that } \\
\text { document that workers have completed reading the FSP. } \\
\text { Each RI verifies that their employees complete the required } \\
\text { reading for their activity. Each employee will electronically sign } \\
\text { the IWSs for any IWS/SPs under which they work. }\end{array}$ \\
\hline $\begin{array}{l}\text { 14.2.4. } \\
\text { Documentation }\end{array}$ & a) & $\begin{array}{l}\text { Provide a system for } \\
\text { documenting that workers } \\
\text { have completed the required } \\
\text { reading. }\end{array}$ & Yes & $\mathrm{FMC} / \mathrm{PMC}$ & $\begin{array}{l}\text { The CMELS Site } 300 \text { Facility manager maintains records that } \\
\text { document that workers have completed reading the FSP. } \\
\text { Each RI verifies that their employees complete the required } \\
\text { reading for their activity. Each employee will electronically sign } \\
\text { the IWSs for any IWS/SPs under which they work. }\end{array}$ \\
\hline 14.2.5. Review & a) & $\begin{array}{l}\text { Regularly review and update } \\
\text { the required reading list. }\end{array}$ & Yes & $\mathrm{FMC/PMC}$ & FSPs are reviewed and re-issued at least every three years. \\
\hline \multicolumn{6}{|l|}{$\begin{array}{l}\text { TIMELY ORDERS } \\
\text { TO OPERATORS } \\
\text { SECTION } 15.0 \\
\end{array}$} \\
\hline \multirow[t]{2}{*}{$\begin{array}{l}\text { 15.2.1. Content and } \\
\text { Format }\end{array}$} & a) & $\begin{array}{l}\text { Describe how special } \\
\text { instructions (short and long } \\
\text { term) will be developed for } \\
\text { communication to } \\
\text { workers/operators. }\end{array}$ & Yes & $\mathrm{FMC} / \mathrm{PMC}$ & $\begin{array}{l}\text { Instructions for work activities are identified through the IWS for } \\
\text { programmatic work activities. Facility instructions (such as shut } \\
\text { down of hoods or retention tanks) are communicated by the } \\
\text { Facility Point of Contact to building residents through e-mail, } \\
\text { building announcements, paper postings, etc. Special } \\
\text { instructions to programmatic workers are communicated directly } \\
\text { by managers and supervisors via e-mail, telephone, and/or } \\
\text { personal communication. }\end{array}$ \\
\hline & & $\begin{array}{l}\text { Document how orders that are } \\
\text { issued to supplement } \\
\text { operating procedures will be } \\
\text { incorporated. }\end{array}$ & Yes & $\mathrm{FMC} / \mathrm{PMC}$ & $\begin{array}{l}\text { Instructions for work activities are identified through the IWS for } \\
\text { programmatic work activities. Facility instructions (such as shut } \\
\text { down of hoods or retention tanks) are communicated by the } \\
\text { Facility Point of Contact to building residents through e-mail, } \\
\text { building announcements, paper postings, etc. Special } \\
\text { instructions to programmatic workers are communicated directly } \\
\text { by managers and supervisors via e-mail, telephone, and/or } \\
\text { personal communication. }\end{array}$ \\
\hline $\begin{array}{l}\text { 15.2.2. Issuing, } \\
\text { Segregating, and } \\
\text { Reviewing Orders }\end{array}$ & a) & $\begin{array}{l}\text { Describe process for issuing } \\
\text { Shift Orders/Instructions to } \\
\text { workers/operators. }\end{array}$ & Yes & $\mathrm{FMC} / \mathrm{PMC}$ & $\begin{array}{l}\text { Instructions are issued through e-mail, building announcements, } \\
\text { phone calls, alpha-numeric pagers, paper postings, in-person } \\
\text { verbally, etc. }\end{array}$ \\
\hline
\end{tabular}




\section{Conduct of Operations Applicability Matrix}

\begin{tabular}{|c|c|c|c|c|c|}
\hline & & $\begin{array}{l}\text { Describe process for issuing } \\
\text { Standing Orders/Instructions } \\
\text { to workers/operators. }\end{array}$ & Yes & FMC/PMC & $\begin{array}{l}\text { Standing orders are documented and issued in the work } \\
\text { authorization documents (IWS's, PWS's, Service Work } \\
\text { Authorization docs, etc) }\end{array}$ \\
\hline $\begin{array}{l}\text { 15.2.3. Removal of } \\
\text { Orders }\end{array}$ & a) & $\begin{array}{l}\text { Remove/cancel expired or } \\
\text { outdated orders. }\end{array}$ & Yes & FMC/PMC & $\begin{array}{l}\text { Cancellation of standing orders are documented and issued in } \\
\text { the work authorization documents (IWS's, PWS's, Service Work } \\
\text { Authorization docs, etc). Cancellation of shift orders is made } \\
\text { through e-mail, building announcements, phone calls, alpha- } \\
\text { numeric pagers, paper postings, in-person verbally, etc. }\end{array}$ \\
\hline \multicolumn{6}{|l|}{$\begin{array}{l}\text { OPERATIONS } \\
\text { PROCEDURES } \\
\text { SECTION } 16.0\end{array}$} \\
\hline $\begin{array}{l}\text { 16.2.1. Procedure } \\
\text { Development }\end{array}$ & a) & $\begin{array}{l}\text { Identify equipment/operations } \\
\text { that require operating } \\
\text { procedures. }\end{array}$ & Yes & FMC/PMC & $\begin{array}{l}\text { The need for operating procedures in accordance with } \\
\text { Document } 3.4 \text { of the ES\&H Manual is determined through the } \\
\text { IWS process. Equipment/systems that need operating } \\
\text { procedures from a programmatic impact standpoint are } \\
\text { managed in accordance with CMLS- } 901 \text {. Instructions for } \\
\text { equipment operation can also be identified through the IWS for } \\
\text { programmatic and facility equipment. }\end{array}$ \\
\hline $\begin{array}{l}\text { 16.2.2. Procedure } \\
\text { Content }\end{array}$ & a) & $\begin{array}{l}\text { Ensure that the content of } \\
\text { operating procedures } \\
\text { conforms to prescribed } \\
\text { guidelines }\end{array}$ & Yes & FMC/PMC & $\begin{array}{l}\text { Document } 3.4 \text { of the ES\&H Manual defines requirements for } \\
\text { operating procedures. CMELS-904 (Control of Unclassified } \\
\text { Management Policies, Plans and Procedures) defines CMELS } \\
\text { requirements for work procedures. } \\
\text { The Site } 300 \text { Facility Manager and Area Supervisors review } \\
\text { FSP S300.8 annually in order to ensure the content of the } \\
\text { Operating Procedures is adequate and correct. }\end{array}$ \\
\hline $\begin{array}{l}\text { 16.2.3. Procedure } \\
\text { Changes and } \\
\text { Revisions }\end{array}$ & a) & $\begin{array}{l}\text { Specify a method for initiating } \\
\text { temporary and permanent } \\
\text { changes to operating } \\
\text { procedures }\end{array}$ & Yes & FMC/PMC & $\begin{array}{l}\text { Document } 3.4 \text { of the ES\&H Manual defines requirements for } \\
\text { operating procedures. CMELS-904 defines CMELS requirements } \\
\text { for work procedures. } \\
\text { The Site } 300 \text { Facility Manager and Area Supervisors review } \\
\text { FSP S300.8 annually in order to ensure the content of the } \\
\text { Operating Procedures is adequate and correct. }\end{array}$ \\
\hline
\end{tabular}




\section{Conduct of Operations Applicability Matrix}

\begin{tabular}{|c|c|c|c|c|c|}
\hline $\begin{array}{l}\text { 16.2.4. Procedure } \\
\text { Approval }\end{array}$ & & $\begin{array}{l}\text { Identify procedure approval } \\
\text { protocol. }\end{array}$ & Yes & $\mathrm{FMC/PMC}$ & $\begin{array}{l}\text { Document } 3.4 \text { of the ES\&H Manual defines requirements for } \\
\text { operating procedures. CMELS-904 defines CMELS requirements } \\
\text { for work procedures. } \\
\text { The Site } 300 \text { Facility Manager and Area Supervisors review } \\
\text { FSP S } 300.8 \text { annually in order to ensure the content of the } \\
\text { Operating Procedures is adequate and correct. }\end{array}$ \\
\hline \multirow[t]{3}{*}{$\begin{array}{l}\text { 16.2.5. Procedure } \\
\text { Review }\end{array}$} & a) & $\begin{array}{l}\text { Identify procedure review } \\
\text { protocol. }\end{array}$ & Yes & $\mathrm{FMC/PMC}$ & $\begin{array}{l}\text { Document } 3.4 \text { of the ES\&H Manual defines requirements for } \\
\text { operating procedures. CMELS-904 defines CMELS requirements } \\
\text { for work procedures. } \\
\text { The Site } 300 \text { Facility Manager and Area Supervisors review } \\
\text { FSP S300.8 annually in order to ensure the content of the } \\
\text { Operating Procedures is adequate and correct. }\end{array}$ \\
\hline & & $\begin{array}{l}\text { Ensure that new operating } \\
\text { procedures and those } \\
\text { undergoing major revision are } \\
\text { verified for correctness and } \\
\text { operationally tested prior to } \\
\text { final approval and use. }\end{array}$ & Yes & $\mathrm{FMC/PMC}$ & $\begin{array}{l}\text { Document } 3.4 \text { of the ES\&H Manual defines requirements for } \\
\text { operating procedures. CMELS-904 defines CMELS requirements } \\
\text { for work procedures. } \\
\text { Additionally, new and revised procedures involving explosives } \\
\text { are reviewed using a formal Peer Review process as described } \\
\text { in section } 3.7 .15 \text { of FSP S300.8, in compliance with the DOE } \\
\text { Explosives Safety Manual (DOE/EV/06194) }\end{array}$ \\
\hline & c) & $\begin{array}{l}\text { Review operating procedures } \\
\text { to ensure they are kept } \\
\text { current. }\end{array}$ & Yes & $\mathrm{FMC/PMC}$ & $\begin{array}{l}\text { Document } 3.4 \text { of the ES\&H Manual defines requirements for } \\
\text { operating procedures. In accordance with the ES\&H Manual, } \\
\text { FSPs are updated at least every three years (the sections } \\
\text { applying to explosives safety controls are reviewed annually) } \\
\text { and IWS/SPS are reviewed at least annually. CMELS-904 } \\
\text { defines CMELS requirements for work procedures. }\end{array}$ \\
\hline $\begin{array}{l}\text { 16.2.6. Procedure } \\
\text { Availability }\end{array}$ & a) & $\begin{array}{l}\text { Copies of applicable operating } \\
\text { procedures are available and } \\
\text { controlled. }\end{array}$ & Yes & $\mathrm{FMC/PMC}$ & $\begin{array}{l}\text { Document } 3.4 \text { of the ES\&H Manual defines requirements for } \\
\text { operating procedures. CMELS-904 defines CMELS requirements } \\
\text { for work procedures. } \\
\text { Rls routinely upload current copies of relevant procedures and } \\
\text { safety plans to their IWSs. }\end{array}$ \\
\hline
\end{tabular}




\section{Conduct of Operations Applicability Matrix}

\begin{tabular}{|c|c|c|c|c|c|}
\hline $\begin{array}{l}\text { 16.2.7. Procedure } \\
\text { Use }\end{array}$ & a) & $\begin{array}{l}\text { Operators/Workers should be } \\
\text { instructed in the use of } \\
\text { procedures. }\end{array}$ & Yes & FMC/PMC & $\begin{array}{l}\text { Document } 3.4 \text { of the ES\&H Manual defines requirements for } \\
\text { operating procedures. CMELS-904 defines CMELS requirements } \\
\text { for work procedures. } \\
\text { RIs routinely upload current copies of relevant procedures and } \\
\text { safety plans to their IWSs. } \\
\text { Activity Responsible Individuals are responsible for ensuring } \\
\text { that workers are trained in the proper use of applicable } \\
\text { procedures. }\end{array}$ \\
\hline \multicolumn{6}{|l|}{$\begin{array}{l}\text { OPERATOR AID } \\
\text { POSTINGS } \\
\text { SECTION } 17.0 \\
\end{array}$} \\
\hline $\begin{array}{l}\text { 17.2.1. Operator } \\
\text { Aid Development }\end{array}$ & a) & $\begin{array}{l}\text { Identify and maintain operator } \\
\text { aids that must be controlled. }\end{array}$ & No & NA & $\begin{array}{l}\text { Operator aids whose accuracy is critical to operating a system } \\
\text { or piece of equipment so that it does not produce a significant } \\
\text { impact to health, safety, the environment, or programs are not } \\
\text { used in these facilities. }\end{array}$ \\
\hline 17.2.2. Approval & a) & $\begin{array}{l}\text { Identify the individual } \\
\text { responsible for approving } \\
\text { operator aids. }\end{array}$ & No & NA & $\begin{array}{l}\text { Operator aids whose accuracy is critical to operating a system } \\
\text { or piece of equipment so that it does not produce a significant } \\
\text { impact to health, safety, the environment, or programs are not } \\
\text { used in these facilities. }\end{array}$ \\
\hline \multirow[t]{2}{*}{ 17.2.3. Posting } & a) & $\begin{array}{l}\text { Ensure that operator aids are } \\
\text { posted so that they do not } \\
\text { obscure or interfere with } \\
\text { instruments or controls. }\end{array}$ & No & NA & $\begin{array}{l}\text { Operator aids whose accuracy is critical to operating a system } \\
\text { or piece of equipment so that it does not produce a significant } \\
\text { impact to health, safety, the environment, or programs are not } \\
\text { used in these facilities. }\end{array}$ \\
\hline & b) & $\begin{array}{l}\text { Ensure that operator aids are } \\
\text { legible and posted as close as } \\
\text { practical to the system or } \\
\text { equipment with which they are } \\
\text { associated. }\end{array}$ & No & NA & $\begin{array}{l}\text { Operator aids whose accuracy is critical to operating a system } \\
\text { or piece of equipment so that it does not produce a significant } \\
\text { impact to health, safety, the environment, or programs are not } \\
\text { used in these facilities. }\end{array}$ \\
\hline
\end{tabular}




\section{Conduct of Operations Applicability Matrix}

\begin{tabular}{|c|c|c|c|c|c|}
\hline $\begin{array}{l}\text { 17.2.4. Use of } \\
\text { Operator Aids }\end{array}$ & & $\begin{array}{l}\text { Operator aid developers and } \\
\text { users should understand their } \\
\text { purpose (e.g. convenience, } \\
\text { not requirement, supplement } \\
\text { to approved procedures) and } \\
\text { limitation (not used in lieu of } \\
\text { approved procedure) }\end{array}$ & No & NA & $\begin{array}{l}\text { Operator aids whose accuracy is critical to operating a system } \\
\text { or piece of equipment so that it does not produce a significant } \\
\text { impact to health, safety, the environment, or programs are not } \\
\text { used in these facilities. }\end{array}$ \\
\hline $\begin{array}{l}\text { 17.2.5. } \\
\text { Documentation }\end{array}$ & a) & $\begin{array}{l}\text { Maintain a listing of all } \\
\text { approved operator aids. }\end{array}$ & No & NA & $\begin{array}{l}\text { Operator aids whose accuracy is critical to operating a system } \\
\text { or piece of equipment so that it does not produce a significant } \\
\text { impact to health, safety, the environment, or programs are not } \\
\text { used in these facilities. }\end{array}$ \\
\hline 17.2.6. Review & a) & $\begin{array}{l}\text { Ensure that operator aids are } \\
\text { regularly reviewed to verify } \\
\text { they are current and } \\
\text { appropriate. }\end{array}$ & No & NA & $\begin{array}{l}\text { Operator aids whose accuracy is critical to operating a system } \\
\text { or piece of equipment so that it does not produce a significant } \\
\text { impact to health, safety, the environment, or programs are not } \\
\text { used in these facilities. }\end{array}$ \\
\hline \multicolumn{6}{|l|}{$\begin{array}{l}\text { EQUIPMENT AND } \\
\text { PIPING LABELING } \\
\text { SECTION } 18.0\end{array}$} \\
\hline $\begin{array}{l}\text { 18.2.1. } \\
\text { Components } \\
\text { Requiring Labeling }\end{array}$ & a) & $\begin{array}{l}\text { Identify and maintain a listing } \\
\text { of equipment and piping that } \\
\text { should be labeled in } \\
\text { accordance with section } \\
\text { 18.2.1. }\end{array}$ & Yes & FMC/PMC & $\begin{array}{l}\text { Plant Engineering Standards PEL-M-11009, (Rev. G or latest } \\
\text { revision) for equipment, and PEL-M-02650, (Rev. A or latest } \\
\text { revision) for piping and valve identification. }\end{array}$ \\
\hline \multirow[t]{2}{*}{$\begin{array}{l}\text { 18.2.2. Label } \\
\text { Information }\end{array}$} & a) & $\begin{array}{l}\text { Use the Plant Engineering } \\
\text { Department standards for } \\
\text { label requirements and } \\
\text { abbreviations. }\end{array}$ & Yes & FMC/PMC & $\begin{array}{l}\text { Plant Engineering Standards PEL-M-11009, (Rev. G or latest } \\
\text { revision) for equipment, and PEL-M-02650, (Rev. A or latest } \\
\text { revision) for piping and valve identification. }\end{array}$ \\
\hline & b) & $\begin{array}{l}\text { Ensure workers are trained or } \\
\text { instructed before performing } \\
\text { maintenance on labeled } \\
\text { equipment. }\end{array}$ & Yes & FMC/PMC & $\begin{array}{l}\text { Plant Engineering Standards PEL-M-11009, (Rev. G or latest } \\
\text { revision) for equipment, and PEL-M-02650, (Rev. A or latest } \\
\text { revision) for piping and valve identification. }\end{array}$ \\
\hline
\end{tabular}




\section{Conduct of Operations Applicability Matrix}

\begin{tabular}{|l|l|l|l|l|}
\hline & a) $\begin{array}{l}\text { Use Plant Engineering } \\
\text { Standards PEL-M-11009, } \\
\text { 18.2.3. Label } \\
\text { (Rev. G or latest revision) (for } \\
\text { equipment) and PEL-M-02650, } \\
\text { (Rev. A or latest revision) (for } \\
\text { piping and valve identification) } \\
\text { for label placement. }\end{array}$ & Yes & FMC/PMC & $\begin{array}{l}\text { Plant Engineering Standards PEL-M-11009, (Rev. G or latest } \\
\text { revision) for equipment, and PEL-M-02650, (Rev. A or latest } \\
\text { revision) for piping and valve identification. }\end{array}$ \\
\hline 18.2.4. Replacing & $\begin{array}{l}\text { a) } \\
\text { Labels }\end{array}$ & $\begin{array}{l}\text { Ensure processes (e.g. post- } \\
\text { maintenance tests, lineup } \\
\text { sheets, etc.) include provisions } \\
\text { to check for labels that are } \\
\text { missing, damaged or have } \\
\text { incorrect information and new } \\
\text { labels are promptly provided. }\end{array}$ & Yes & FMC/PMC \\
\hline
\end{tabular}

